Saint Louis University School of Law

Scholarship Commons

All Faculty Scholarship

2011

Choosing Justices: How Presidents Decide

Joel K. Goldstein

Follow this and additional works at: https://scholarship.law.slu.edu/faculty

Part of the Courts Commons, President/Executive Department Commons, and the Supreme Court of the United States Commons 
S A I N T L O U I S

$\begin{array}{llllllllll}U & N & \text { I } & V & E & R & S & \text { I } & T & Y\end{array}$

\section{SCHOOL OF LAW}

\section{SAINT LOUIS UNIVERSITY SCHOOL OF LAW \\ Legal Studies Research Paper Series}

No. 2011-09

Choosing Justices: How Presidents Decide

Forthcoming in Stetson Law Review

Joel K. Goldstein

Saint Louis University School of Law 
Choosing Justices: How Presidents Decide

\author{
Joel K. Goldstein* \\ Vincent C. Immel Professor of Law \\ Saint Louis University School of Law \\ 314-977-2782 \\ goldstjk@slu.edu
}

\footnotetext{
*Vincent C. Immel Professor of Law, Saint Louis University School of Law. An earlier version of this paper was presented as part of a panel discussion on selection of federal judges at the Southeastern Association of Law Schools annual meeting on August 7, 2009. I benefited from the discussion by my fellow panelists Bill Marshall and Ron Rotunda and by those in attendance. I am grateful to Mark Killenbeck and Brad Snyder for very helpful comments on a more recent draft and to Stacy Osmond for research assistance.
} 


\title{
Choosing Justices: How Presidents Decide
}

\begin{abstract}
Presidents play the critical role in determining who will serve as justices on the Supreme Court and their decisions inevitably influence constitutional doctrine and judicial behavior long after their terms have ended. Notwithstanding the impact of these selections, scholars have focused relatively little attention on how presidents decide who to nominate. This article contributes to the literature in the area by advancing three arguments. First, it adopts an intermediate course between the works which tend to treat the subject historically without identifying recurring patterns and those which try to reduce the process to empirical formulas which inevitably obscure considerations shaping decision. The article argues that a more analytically useful approach views the selection as turning upon the interaction of three variables - pool, context and presidential idiosyncrasy - each of which consists of a variety of other factors. This article examines Supreme Court nominations since 1900 to develop these points. Use of that period illustrates the taxonomy described above yet it also exposes the dynamic nature of the process which leads to the article's second mission. It explains how larger changes in other governmental institutions and in society have transformed the process by which presidents choose Court nominees. Those changes occurred independent of any formal constitutional amendment, thereby offering a case study in how constitutional institutions evolve in response to informal developments. Finally, the article argues that the changes in the process have increased the likelihood that presidents will nominate competent justices but lessens the prospects that they will choose potentially great jurists.
\end{abstract}




\section{Choosing Justices: How Presidents Decide}

Presidents of the United States play the critical role in determining who serves on the Supreme Court. Although the Constitution subjects these presidential nominations to the advice and consent process, the Senate's role, though important, is reactive and secondary. Only the president can nominate and that power confers a huge advantage in composing the Court. ${ }^{1}$ Presidential nominees to the Court almost always win confirmation. Since 1900 , about $87 \%$ of those selected as nominees for the Court were confirmed. ${ }^{2}$ This high rate of presidential success does not mean that a president has carte blanche in choosing a nominee. As will be shown below, the success rate traces in part to presidential skill in choosing confirmable candidates. Nonetheless, the figures confirm that the Court's composition correlates closely to decisions presidents make regarding who to nominate.

The impact of those presidential decisions reverberates for generations. Those chosen generally remain on the Court well beyond the term (and often the life) of their benefactor. Justices William Brennan and Byron "Whizzer" White, for instance, served during the tenures of eight presidents; Justice (and Chief Justice) William Rehnquist overlapped seven.

These two factors, the president's dominance of Supreme Court selection and the lengthy service of those he chooses, interact with a third variable to compound the significance of the subject. The Court's position atop the judicial hierarchy affords its nine members extraordinary

\footnotetext{
${ }^{1}$ Michael J. Gerhardt, Judicial Selection as War, 36 U.C. DAVIS L. REV. 667, 671 (2003) (emphasizing institutional strength of president's position); David R. Stras \& Ryan W. Scott, Navigating the New Politics of Judicial Appointments, 102 Nw. U. L. REV. 1869, 1872 (2008) (same).

${ }^{2}$ Arguably the rate is even higher since the nine unsuccessful nominees include John Roberts who was initially nominated to replace Justice Sandra Day O'Connor, a nomination which was withdrawn so he could be nominated as chief justice. The success rate was lower in earlier periods. Over the course of American history it is approximately $78 \%$.
} 
influence on the shape of American law. Each justice wields a portion of the judicial power to check the work of the other branches of the national government as well as that of other units in the federal system.

For these reasons, few presidential decisions, regarding personnel especially, rival Supreme Court nominations in their enduring consequences. Many presidents have suggested as much in their public pronouncements. Although much has been written regarding the deficiencies of the Senate's confirmation process, ${ }^{3}$ relatively little scholarly attention has explored how presidents make these decisions. That neglect leaves a gap not only in the literature on the presidency but also in that regarding the Court, its composition and the shape of American law, particularly constitutional law. Ultimately the content and quality of judicial doctrine turns on the identity, competency and dispositions of the justices on the Court, and those characteristics are largely determined by decisions of the appointing presidents acting individually at different times.

Although these presidential decisions clearly have a major impact on American law as well as on governmental institutions, knowledge regarding them is relatively rudimentary. Supreme Court nominations are sui generis in two respects. They are materially different from selections a president makes for other offices. The pattern of a president's other decisions, even regarding personnel, does not forecast his Supreme Court nominees. Moreover, each Court nomination differs from every other one. For reasons explained below, different presidents choose differently and any one president is likely to act differently in filling Court vacancies which arise on his watch.

\footnotetext{
${ }^{3}$ See, e.g., Stephen L. Carter, The Confirmation Mess: Cleaning Up The Federal Appointments Process (1994); Christopher L. Eisgruber, The Next Justice: Repairing The Supreme Court Appointments Process (2007).
} 
These distinctive characteristics of presidential selection of Supreme Court nominees present a paradox. The uniqueness of these decisions mandate separate consideration of the topic, especially given its vital importance to American law and government. It is essential to focus on presidential choice to understand why those who interpret law on the Court achieved their exalted positions. Yet the varying nature of presidential behavior suggests that such an examination will not yield reliable formulas to explain the past or predict the future.

Although the topic resists algorithmic precision, the enterprise lends itself to some systematic discussion provided, at least, that some play is built into the joints. The effort to formulate rules to predict presidential choice represents a futile quest, yet studying the dynamics of the selection of justices allows generalizations which contribute to understanding of presidential behavior in this area and of the Court it produces.

The thesis of this article comes in three-parts. First, it argues that Supreme Court selection is too diverse to lend itself to formulaic treatment yet sufficiently regular to suggest recurring patterns. Most of the article is dedicated to providing a taxonomy of Supreme Court selection. More specifically, it argues that Supreme Court nominations are best understood as the product of the interaction between three interrelated and dynamic variables- the pool of potential candidates, the context in which the nomination is made, and presidential idiosyncrasy. The factors are interrelated because the pool from which a president chooses depends on the context surrounding the choice and the general criteria and dispositions of the president and those he involves in the search. Although certain patterns recur, Supreme Court nominations are each distinctive choices. The pool, context and selector differ from one presidency to the next. Indeed the pool and context vary within a single presidency, and a president making later nominations has generally learned from experiences and accordingly is not quite the same person 
who made the earlier choices. Perceived political and ideological compatibility helps narrow the pool $^{4}$ yet presidents do not simply choose the candidate they think best reflects their ideology subject to concessions made to find a confirmable choice as some suggest. ${ }^{5}$ Presidential behavior here is subject to multi-factored influences and cannot be reduced to any such formulaic approach. The enterprise is more a matter of serendipity than of science.

But the history of past presidential nominations must be carefully used. It can furnish insights but can also lead us badly astray. This observation leads to the second point. Presidents today act within a different system than did their predecessors, even their recent predecessors, even though the relevant constitutional arrangements have presented the same formal features since the founding. Even though no amendment has addressed the president's constitutional role in choosing Supreme Court nominees, the system in which presidents now operate has evolved due to the unanticipated consequences of formal and informal developments. The article suggests that presidential choice, and accordingly Court composition, cannot be understood without recognizing the dynamic quality of a seemingly static system. The system which now exists is, in some respects, quite different from that of even recent times. Like Theodore Roosevelt, Franklin Roosevelt and Richard Nixon, Barack Obama's choices were the product of the interaction between his options, the circumstances in which the decisions were made and presidential personality. Yet Obama operated in a system that was somewhat different than these and most other twentieth century presidents.

\footnotetext{
${ }^{4}$ Henry J. Abraham, Justices, Presidents, and Senators: A History of U.S. Supreme Court Appointments FROM WASHINGTON TO BUSH II 3 (5th ed. 2008).

${ }^{5} C f$. Christine Nemacheck, Strategic Selection: Presidential Nomination of Supreme Court Justices From Herbert HoOver Through GeOrge W. Bush 111, 127-28 (2007) (arguing that presidents who believe themselves freed of confirmation constraints select nominee from pool who is most ideologically compatible).
} 
Finally, these systemic changes have important consequence for the quality and characteristics of those nominated to serve on the Court. Their impact on Court nominations is mixed. The changes surrounding the process increase the likelihood that presidents will choose competent nominees for the Court yet they reduce the likelihood they will select those whose past service distinguishes them as courageous leaders likely to move the law in constructive directions.

The article proceeds as follows. Section I develops some of the premises stated above and presents a general outline of the landscape in which presidents have made Supreme Court nominations since 1900. That cutoff date, though somewhat arbitrary, focuses on the most recent half of American history and furnishes a sufficiently large sample from which to discern patterns. As explained below, the data from that period is subject to different use in developing the three parts of the thesis outlined above. Sections II through V develop a general taxonomy of presidential decision. In particular, section II identifies characteristics about the pool of nominees. Section III describes how contextual factors have affected selection. Section IV demonstrates the role of presidential idiosyncrasy in making selections. Section V discusses the interaction of these factors and argues that efforts to produce a more formulaic account should be regarded skeptically. For purposes of developing the taxonomy, the three variables accurately portray presidential decision during the entire period even though some changes in American government and politics since 1900 render some of the specific practices or considerations from earlier years less relevant now. Section VI draws from the data to explore developments during the period which produced enduring change rather than simply short-term fluctuations. This section presents a more particular portrait of the current system and illustrates how it is a product of changes in other institutions and in society more generally. Section VII offers some 
observations on the implications of these changes for the quality and characteristics of those who now become justices.

I. A General Survey of the Landscape

\section{A. The Significance of the Decision}

The significance of Supreme Court nominations traces to the justices' role atop one of the three branches of America's national government, the scarcity of their number, and their life tenure. $^{6}$ Presidents have recognized the importance of their Supreme Court nominees. ${ }^{7}$ President Ronald Reagan put it well when he said, "Those who sit in the Supreme Court interpret the laws of our land and truly do leave their footprints on the sands of time. Long after the

\footnotetext{
${ }^{6}$ U.S. CONST. art. III, $\S 1$ (conferring life-tenure on judges of Supreme Court).

${ }^{7}$ See, e.g., Address to the Nation Announcing Intention to Nominate Lewis F. Powell, Jr., and William H. Rehnquist to Be Associate Justices of the Supreme Court of the United States, PUB. PAPERS 1052 (October 21, 1971) (Nixon labeling Supreme Court nominations as "[b]y far the most important appointments" a President makes); Remarks Announcing Intention to Nominate John Paul Stevens to be an Associate Justice of the Supreme Court, PUB. PAPERS 1917(November 28, 1975) ("The nomination of a Justice of the United States Supreme Court is one of the most important decisions a President has to make.”); Remarks Announcing the Intention to Nominate Sandra Day O'Connor to Be an Associate Justice of the Supreme Court of the United States, PuB. PAPERS 596 (July 7, 1981) (Ronald Reagan describing Court nominations as "the most awesome appointment" a President makes); Remarks Announcing the Nomination of David H. Souter to Be an Associate Justice of the Supreme Court of the United States and a Question-and-Answer Session with Reporters, PUB. PAPERS 1046-47 (July 23, 1990) ("Few duties are more important in discharging that obligation than my responsibility, under article II, section 2 of our Constitution, to select from among all possible choices one nominee to fill a vacancy on the Supreme Court of the United States.”); Remarks at a Republican Party Fundraising Luncheon in Philadelphia, Pennsylvania, PUB. PAPERS 1054 (July 24, 1990) ("So, the appointment of a Supreme Court Justice becomes one of the most serious responsibilities facing any President."); Exchange with Reporters in Atlanta, PUB. PAPERS 325(March 19, 1993) (Bill Clinton said "that there are few decisions the President makes which are more weighty, more significant, or can have a greater impact on more Americans than an appointment to the Supreme Court."); see also The President's News Conference, PUB. PAPERS 798 (July 28, 1965) (In announcing Fortas' nomination, Johnson proclaimed that “[t]he President has few responsibilities of greater importance or greater consequence to the country's future than the constitutional responsibility of nominating Justices for the Supreme Court of the United States." The Fortas nomination was the third item at his press conference, following a long defense of his Vietnam policy including the explanation of why Johnson was sending 50,000 more troops to Vietnam and raising the monthly draft call from 17,000/month to 35,000/month and the appointment of NBC newsman John Chancellor to direct Voice of America).
} 
policies of Presidents and Senators and Congressmen of any given era may have passed from public memory, they'll be remembered."

Most presidents make few Supreme Court nominations. Since 1900, the 20 presidents have nominated 68 persons $^{9}$ for the Supreme Court. Individual presidents have nominated anywhere from zero (Jimmy Carter) ${ }^{10}$ to nine (Franklin D. Roosevelt) potential justices. On 59 occasions, the nominee was confirmed and took office. ${ }^{11}$ The average number of Court nominations per president over the period is 3.4; the average number of seats filled, 2.9.

As suggested above, the distribution of nominations per president is uneven. Eight presidents made two or fewer nominations ${ }^{12}$ and two made only three nominations. ${ }^{13}$ Only two presidents - Taft and Nixon — nominated more than one justice/year. Accordingly, more data

\footnotetext{
${ }^{8}$ Remarks Announcing the Intention to Nominate Sandra Day O'Connor to Be an Associate Justice of the Supreme Court of the United States, PUB. PAPERS 596 (July 7, 1981). See also Remarks on the Nomination of Sonia Sotomayor to Be a Supreme Court Associate Justice_PUB. PAPERS _ (May 26, 2009) (forthcoming [month] [year]), available at http://www.presidency.ucsb.edu/ws/index.php?pid=86204\&st=sotomayor\&st1 $1=($ President ("Of the many responsibilities granted to a President by our Constitution, few are more serious or more consequential than selecting a Supreme Court Justice. The members of our highest court are granted life tenure, often serving long after the Presidents who appointed them, and they are charged with the vital task of applying principles put to paper more than 20 [2; White House correction] centuries ago to some of the most difficult questions of our time.").

${ }^{9}$ This number counts only once, Justices Butler and Harlan, each of whom were nominated twice for the same seat, but counts John Roberts, who was nominated for two different vacancies, twice. It also includes Judge Douglas Ginsburg who President Reagan announced as his nominee but whose name was never formally submitted.

${ }^{10}$ President William McKinley nominated none during the twentieth century but one (Joseph McKenna) in 1897 who is not included in this study.

${ }^{11}$ The nine nominees who did not take office were Judge John Parker (Senate rejected), Justice Abe Fortas (Senate filibustered; nomination withdrawn), Judge Homer Thornberry (no Senate action since nomination contingent on Fortas elevation), Judge Clement Haynsworth (Senate rejected), Judge G. Harold Carswell (Senate rejected), Judge Robert Bork (Senate rejected), Judge Douglas Ginsburg (intent to nominate announced but name not submitted once Ginsburg withdrew), Judge John Roberts for O'Connor seat (nomination withdrawn and resubmitted for Chief Justice), and Harriet Miers (nomination withdrawn).

${ }^{12}$ McKinley, Coolidge, Kennedy, Ford, Carter, Bush (41), Clinton, Obama.

${ }^{13}$ Theodore Roosevelt and Wilson.
} 
exists for some presidents, and relatively little exists for most. The uneven distribution may overemphasize the approaches of presidents who made multiple nominations and undervalue those of chief executives who made few selections.

Table A Supreme Court Nominations Per President

$\begin{array}{cl}\text { Number of Nominations } & \text { Presidents } \\ 0 & \text { McKinley, Carter } \\ 1 & \text { Coolidge, Ford } \\ 2 & \text { Kennedy, Bush (41), Clinton, Obama } \\ 3 & \text { T. Roosevelt, Wilson } \\ 4 & \text { Harding, Hoover, Truman, Johnson, Bush (43) } \\ 5 & \text { Eisenhower } \\ 6 & \text { Taft, Nixon, Reagan } \\ 7 & \text { None } \\ 8 & \text { None } \\ 9 & \text { F. Roosevelt }\end{array}$

Some presidents who had relatively short tenures filled more vacancies than others who served longer periods. For instance, Woodrow Wilson, who completed two full terms and Theodore Roosevelt who almost did, each filled three Court vacancies. The intervening president, William Howard Taft, served half as long but appointed twice as many justices. Warren Harding made four appointments in less than $2 \frac{1}{2}$ years and Herbert Hoover made four nominations in one term, whereas the intermediate president, Calvin Coolidge, served $5 \frac{1}{2}$ years 
yet had only one opening. Since justices hold office during "good behavior,"14 their service ends at unpredictable times. Bill Clinton and George W. Bush each served eight years yet Clinton's two vacancies occurred within a year early in his first term whereas Bush's came within a few months at the beginning of his second. The irregularity of vacancies further varies the context each president faces.

Although it is tempting to attribute the fact that Franklin Roosevelt filled nine vacancies to the unprecedented length of his presidency (he was elected four times and served more than 12 years), all nine vacancies came within less than a 5 1/2 year period from June 2, 1937 (when Justice Willis Van Devanter retired) and October 2, 1942 (when Justice James Byrnes resigned). Presidents Theodore Roosevelt, Wilson, Coolidge, Truman, Eisenhower, Nixon, Reagan, Clinton and Bush (43) served longer than that period yet were presented with between one (Coolidge) and five (Eisenhower) vacancies.

Two other factors have influenced the number of nominations some presidents made. Presidents who make unsuccessful nominations have the opportunity to choose multiple candidates for a vacancy (unless the failed nominations come at the end of a presidential term as was the case with Johnson's ill-fated selections of Abe Fortas and Homer Thornberry). Hoover made two nominations to fill the vacancy which the death of Justice Edward Sanford in 1930 produced, Nixon made three nominations to succeed Fortas, Reagan chose three men to replace Lewis Powell, and Bush (43) made three to follow Justice Sandra Day O'Connor, although one

\footnotetext{
${ }^{14}$ U.S. CONST. art. III, $§ 1$ ("The Judges, both of the supreme and inferior Courts, shall hold their Offices during good Behavior, and shall, at stated Times, receive for their Services a Compensation which shall not be diminished during their Continuance in Office.").
} 
of those, that of then Judge John Roberts, was withdrawn to be resubmitted to fill the vacancy the death of Chief Justice Rehnquist created.

Presidents occasionally engineer vacancies in three ways. Five times since 1900, a president has nominated an associate justice, or one nominated for that position, to be chief justice, thereby creating another selection opportunity. ${ }^{15}$ Two presidents persuaded a justice to leave the Court to accept an executive branch position. ${ }^{16}$ On two occasions, presidents created conditions which encouraged justices to resign. Johnson's nomination of Ramsay Clark as Attorney General induced Clark's father, Justice Tom Clark, to resign to avoid conflicts of interest, thereby creating the vacancy Johnson used to nominate Thurgood Marshall to the Court. Nixon pressured Fortas to resign by having the justice department initiate criminal investigations against him, his wife and other close associates with the implicit suggestion that his resignation would end the inquiries. ${ }^{17}$

B. The Uniqueness of the Decision

\footnotetext{
${ }^{15}$ The five instances involved the elevations of Justices Edward White (1910), Harlan Fiske Stone (1941), and Rehnquist (1986) to Chief Justice, the attempted elevation of Fortas (1968) and the withdrawal of Roberts as the nominee to replace Justice O'Connor and submission of his name to replace Rehnquist (2005).

${ }^{16}$ Franklin D. Roosevelt prevailed on Jimmy Byrnes to leave the Court in 1942 to head the Office of Economic Stabilization and Johnson persuaded Arthur Goldberg to leave the Court to become Ambassador to the United Nations. Robert Dallek, Flawed Giant: Lyndon Johnson ANd His TimeS, 1961-1973, 234 (1998); LAURA KALMAN, ABE ForTAS: A BIOGRAPHY 241 (1990); Interview by Ted Gittinger with Arthur Goldberg 1-2 (March 23, 1983) (transcript available at LBJ Library Oral History Project http://www.lbjlib.utexas.edu/johnson/archives.hom/oralhistory.hom/GoldbergA/goldberg.asp). Goldberg claimed Johnson had previously asked him to be Attorney General and that Johnson aides had raised the possibility of his serving as secretary of Health, Education and Welfare. Ultimately, Johnson appealed to Goldberg's vanity and may have suggested that the rode to the vice presidency ran through the United Nations, not the Court. In addition, Harry S. Truman offered Justice William O. Douglas the vice-presidential nomination in 1948 and appointment as Secretary of Interior in 1941; Douglas declined each time.

${ }^{17}$ John W. Dean, The Rehnquist Choice: The Untold Story of the Nixon ApPointment That Redefined THE SUPREME COURT 4-11 (2001).
} 
In addition to occurring infrequently, Supreme Court nominations are unique. Presidents have reason to view them quite differently than any other personnel decisions they make.

Of course, presidents nominate other judges but the surrounding circumstances are entirely different. Unlike appointments to the lower federal courts, Supreme Court nominations are rare, highly visible and made without the expectation that politicians from particular states are entitled to influence. Presidents become more involved in selecting nominees for the Court than for other judicial positions. ${ }^{18}$ Virtually all lower federal court judges will toil far from the national spotlight. The work of a justice is much more conspicuous. Decisions of a lower court judge will rarely, if ever, impact administration objectives; the Court's work has far greater and more regular consequence. Although legal competence is a relevant consideration for any judicial nomination, the level of distinction sought is higher, the scrutiny is greater and the requisite skills are different for the Court than for virtually all lower court nominations.

Skill as a jurist and knowledge of the law are not criteria for most other presidential appointments. Other material differences exist, too. Unlike cabinet selections, a Supreme Court nominee serves in the judicial, not executive, branch, and accordingly the Constitution dictates an entirely different president-justice relationship from that of president-cabinet member. A cabinet member is the president's subordinate who is largely subject to presidential control and removal, a relationship which flows from constitutional text ${ }^{19}$ and precedent. The latter exercises power in a separate institution which serves, in part, to check executive behavior. The constitutional difference carries other implications. The senate has greater reason to defer to the president in choosing those who will help discharge his responsibility than in selecting justices

\footnotetext{
${ }^{18}$ Nicholas Deb. KatzenBaCh, Some OF It Was Fun 56 (2008).

${ }^{19}$ U.S. CONST. art. II, $\S 1$ ("The executive Power shall be vested in a President of the United States of America.").
} 
who will check legislative as well as executive conduct and who will do so long after the president departs the scene. Moreover, a president does not anticipate working with, or generally even having anything more than casual future contact with, a justice. The president will no doubt prefer a justice likely to interpret law in a manner consistent with administration objectives but the president is less likely to value personal compatibility given the infrequency of contact and his lack of responsibility for the justice's performance. Whereas cabinet members must be loyal, constitutional norms dictate that a judge purge any feelings of gratitude in discharging his duties. Finally, the president makes numerous cabinet choices but few to the Court.

Supreme Court nominations most resemble vice-presidential selections. Like the choice of a running mate, they are unique, significant, and highly visible. Since vice presidents, like justices, have tenure of sorts, albeit for only four years, neither is constitutionally accountable to the president, although political considerations give vice presidents incentive to support the chief executive. Yet again, the differences exceed the similarities. Unlike vice-presidential selections, the choice of a Supreme Court nominee is not generally made in immediate anticipation of a presidential campaign. Court vacancies occur unpredictably within the four year presidential term. Unlike a vice-presidential candidate, the Supreme Court nominee is not on the ticket and is not presented to the electorate as the presidential successor, thereby reducing, but not eliminating, the personal consequences of the choice to the President. ${ }^{20}$ Unlike justices, vice presidents have regular access to the president and help him discharge his duties.

\footnotetext{
${ }^{20}$ See generally Joel K. Goldstein, The Modern American Vice Presidency: The Transformation of A POLITICAL INSTITUTION 46-89 (1982).
} 
Presidential nominations to the Supreme Court are, accordingly, peculiar presidential acts. A president's performance elsewhere may give some hints regarding how he will handle nominations to the highest Court but the distinctive elements may produce unpredictable presidential behavior. Accordingly, the topic merits separate study.

\section{The Gaps in the Existing Literature}

That has rarely occurred. Neither the importance nor the uniqueness of presidential selection of justices has produced an account which furnishes a convincing framework to understand how presidents make those calls. Space does not allow discussion of all of the major works on the subject but a few major accounts are mentioned below to illustrate prior treatments.

Some admirable works on the subject treat the subject historically, by providing case studies or presenting the chronology of presidential nominations. In his classic work, Henry J. Abraham traces the history of presidential nominations to the Court. Abraham identified a "quartet of steadily occurring criteria" as motivating nominations, namely objective merit, friendship, representation of particular areas, groups or interests, and "political and ideological compatibility" ${ }^{21}$ with the latter as the "controlling factor." These factors are important but this formulation fails to account adequately for the complex and dynamic nature of the enterprise. Although it disclosed some patterns it failed to explain a good deal of presidential behavior. How does a president decide between prospective nominees when he is politically and ideologically compatible with each? Why do different presidents seek to favor different areas, groups or interests? Nor does it explain why the same President appoints people who are quite

\footnotetext{
${ }^{21}$ Abraham, supra note 4, at 2; see also Richard DAvis, Electing Justice: Fixing the Supreme CourT NOMINATION PROCESS 41-51 (2005) (following Abraham's criteria); MichaEL GERHARDT, THE FederAL Appointments Process: A CONSTitutional AND Historical Process 129 (stating that different presidents consider merit, friendship, diversity and philosophy).
} 
different from one another. Why did Woodrow Wilson nominate James McReynolds and Louis D. Brandeis, why did Reagan nominate O’Connor and Antonin Scalia, why did George H.W. Bush nominate David Souter and Clarence Thomas? Or for that matter why did George W. Bush choose Roberts, Harriet Miers and Sam Alito for the same seat in that order?

Christine Nemacheck adopted a quite different approach. Based on archival research, she developed short lists from which recent presidents have worked and argued that presidents choose strategically "to limit their uncertainty about two major factors in the appointment process: the future behavior of their nominees once confirmed and sworn in ... and the likelihood of Senate confirmation."22 Nemacheck suggested that presidents "pursue an information strategy" regarding their selections ${ }^{23}$ to "select the most ideologically compatible candidates when they perceive confirmation constraints to be less restrictive on their choice." 24 Presidents must, however, accommodate their strategies to the imperative that their nominee win support of a senate majority. Thus, presidents facing a cross-party senate "follow a political strategy" to select a confirmable candidate. ${ }^{25}$

Nemacheck's account convincingly argues that presidents act strategically in choosing justices as they do in other decision-making. ${ }^{26}$ Yet it is unconvincing in its suggestion that presidents choose the most ideologically compatible candidate absent confirmation constraints

\footnotetext{
${ }^{22}$ NEMACHECK, supra note 5, at 29.

${ }^{23} I d$. at 111.

${ }^{24} I d$. at 127.

${ }^{25} I d$. at 131.

${ }^{26}$ See generally George C. Edwards, III, The Strategic President: Persuasion AND OpPortunity in Presidential Leadership (2009); Richard E. Neustadt, Presidential Powel and the Modern Presidents (1990).
} 
and alternatively seek one who is confirmable. Surely presidents have weighed those factors heavily but an account which focuses on ideology and confirmation oversimplifies a multifaceted process. Often considerations other than choosing the most ideologically compatible candidate influence presidents even when they do not face serious Senate constraints.

Finally, through a series of fascinating case studies, David Yalof shows that the ultimate selection is often the product of a battle between factions within an administration which the president must arbitrate. ${ }^{27}$ A president often depends on advisers whose interests may not coincide with his own. Yalof identifies an aspect of the process but does not provide a full account of how the selection occurs or how presidents decide.

Although these presidential decisions can be examined "systematically," 28 the number of factors involved and their varying weight in different administrations, and at different times within each administration, necessarily means that the "system" must have a good deal of play in the springs. Continuities exist yet each choice is unique.

Ultimately, a president's Supreme Court choice turns upon three variables - the pool of available candidates, the context in which the choice is made, and the idiosyncrasies of the president. Any effort to predict, assess or understand a particular Court nomination or the way in which justices are nominated must consider those three components and their interaction. The next three sections discuss them in turn drawing from nominations since 1900.

\footnotetext{
${ }^{27}$ David Alistair Yalof, Pursuit of Justices: Presidential Politics And the Selection of Supreme Court NOMINEES 3 (1999).

${ }^{28}$ See, e.g., NEMACHECK, supra note 5 , at 7.
} 
Data from that period illustrates the role and importance of these three variables in shaping choice. One caveat must be kept in mind. Presidential selection today has changed from 1900 or from 1950 or even 1980. Although the three variables of pool, context and presidential idiosyncrasy remain helpful organizing factors, some of the particular considerations within each category are less relevant today than they once were. Sections VI and VII adjust for those changes.

\section{Forming the Pool}

In one sense, presidents choose Supreme Court nominees from a large pool of potential candidates. The Constitution prescribes no qualification for appointment to the Court except to prohibit a religious test, ${ }^{29}$ a requirement sometimes honored in the breach. Although the pool of eligible nominees technically is unbounded, in practice several characteristics define and limit it. In fact, the various factors often work together to provide a president with a relatively small pool of viable candidates.

First, every Supreme Court justice has been a lawyer. Occasionally presidents consider, but never nominate, non-lawyers. ${ }^{30}$

Second, Supreme Court nominees generally are drawn from those between ages 47 and 62. Although the youngest nominee since 1900, William O. Douglas, was 40 when nominated,

\footnotetext{
${ }^{29}$ U.S. CONST. art. VI, cl. 3 ("The Senators and Representatives before mentioned, and the Members of the several State Legislatures, and all executive and judicial Officers, both of the United States and of the several States, shall be bound by Oath or Affirmation, to support this Constitution; but no religious Test shall ever be required as a Qualification to any Office or public Trust under the United States.”).

30 See Christopher Eisgruber, Constitutional Self Government 66-68, 208-09 (2001) (discussing the advantages and disadvantages of the lawyers' monopoly); Philip B. Kurland, The Appointment and Disappointment of Supreme Court Justices, 1972 LAW \& SOC. ORD. 183, 189 (1972) (arguing for need for justices to be lawyers); see also EDWIN M. YODER, JR., VACANCY: A JUdiCIAL MiSADVENTURE (2010) (a novel regarding appointment of nonlawyer to Court).
} 
and the oldest, Stone, was 68 , when named chief justice, most - 40 of the 68 - were in their fifties. Only six were younger than 47 when nominated ${ }^{31}$ and six were 63 or over; $^{32}$ accordingly 56 of the 68 nominees ( $82 \%)$ were within the 47 to 62 range. Those nominated to be chief justice have tended to be older; only three (Roberts, 50; Fortas, 58; and Vinson, 56) of the ten were under 60 and four of the six who were 63 or over when appointed were chief justices. ${ }^{33}$

Third, the available pool differs depending on the president's party identification. Not surprisingly, presidents generally consider and choose justices who share their party affiliation. Presidents nominated someone from the opposing party on only ten of the 68 instances or $14 \%$ of the time (Table B). ${ }^{34}$ Two of the cross-party nominees were associate justices elevated to be chief justices, nominations which did not alter the Court's party composition. ${ }^{35}$ Four presidents seemed to want to make a cross-party selection. Harding chose Pierce Butler, a Minnesota Democrat, in part because the Court then included only two Democrats. ${ }^{36}$ Franklin Roosevelt thought it prudent to elevate a Republican, Stone, to chief justice to foster national unity on the eve of war. When Owen Roberts retired early in the presidency of Harry S. Truman, the president concluded he should appoint a Republican to demonstrate bipartisanship and since only

\footnotetext{
${ }^{31}$ John Parker, William Douglas, Potter Stewart, Byron "Whizzer" White, Douglas Ginsburg, and Clarence Thomas.

${ }^{32}$ Horace Lurton, Edward White, William Howard Taft, Charles Hughes, Harlan Fiske Stone and Lewis Powell. Senator Borah opposed Taft's nomination in part based on his age, arguing that Taft was within seven years of the age of incompetence. Ex-President Taft Succeeds White as Chief Justice, N.Y. TIMES, July 1, 1921, at 1.

${ }^{33}$ White, Taft, Hughes, and Stone. The average age at appointment as chief justice since 1900 was 61.

${ }^{34}$ I have not included Wilson's nomination of Louis Brandeis and Roosevelt's of Felix Frankfurter as cross-party nominees since in each case the judicial nominee had been a strong supporter of the President when he ran for office.

${ }^{35}$ Those two instances were President Taft's elevation of Justice Edward White in 1910 and President Franklin Roosevelt's elevation of Stone in 1941.

${ }^{36}$ DAVID J. DANELSKI, A SuPREME COURT Justice Is APPOINTED 84, 86-87 (1980).
} 
one Republican remained on the Court. ${ }^{37}$ Eisenhower chose Brennan, a New Jersey Democrat. But generally, presidents have considered and selected nominees from their party.

Cross-party nominees are becoming rarer. The last such nomination, Powell in 1971, occurred 40 years ago. Particularly in modern times, Democratic and Republican Presidents consider distinctive pools with no overlap. ${ }^{38}$ For instance, a Democratic president would not have appointed Powell to the Court in 1971 or considered Senator Robert Byrd as did Nixon. ${ }^{39}$

\section{Table B Cross-party Nominees Since 1900}

$\underline{\text { Year }}$

1909

1910

1910

1922

1932

1941

1945

1956

1969

1971 $\underline{\text { President }}$

Taft

Taft

Taft

Harding

Hoover

F. Roosevelt

Truman

Eisenhower

Nixon

Nixon
Nominee

Horace Lurton

Edward White

Joseph Lamar

Pierce Butler

Benjamin Cardozo

Harlan Fiske Stone

Harold Burton

William Brennan, Jr.

Clement E. Haynsworth, Jr.

Lewis Powell, Jr.

\footnotetext{
${ }^{37}$ YALOF, supra note 27, at 21-26.

38 NemACHeCK, supra note 5, at 152-55 (listing those of shortlists of Presidents Ford to Bush (43)). Only Judge Amalya Kearse, a Carter appointee to the United States Court of Appeals for the Second Circuit, appears on crossparty lists of Reagan and Clinton yet it seems inconceivable that Reagan would have selected her and her inclusion on his lists probably reflects a desire to cover demographic bases.

${ }^{39}$ DEAN, supra note 17 , at $126,133-36$.
} 
Fourth, candidate availability, as well as presidential preference, shapes the pool from which a president chooses. Some attractive candidates find other career options more appealing than serving on the Court. ${ }^{40}$ Presidents can’t always get who they want.

Conversely, other names land in pools repeatedly, sometimes lending a short list a "round up the usual suspects" quality. Some eventual nominees were passed over before being chosen; ${ }^{41}$ other prospective candidates were frequently listed but never selected. ${ }^{42}$

\footnotetext{
${ }^{40}$ Taft declined spots on the Court in 1902-1903, to complete his work in the Philippines and, in 1906, to seek the presidency. Moreover, Taft wanted to be chief justice, a position not then open. AlPHEUS ThOMAS MASON, William Howard Taft: Chief Justice 17-33 (1964); A.L Todd, Justice on Trial: The CaSe Of Louis D. BRANDEIS 23-29 (1964). Senator and former Attorney General Philander Knox declined Roosevelt's offer in 1906 as did Secretary of State Elihu H. Root. ABRAHAM, supra note 4, at 129. Attorney General Francis Biddle reportedly declined when Byrnes' resignation created Roosevelt's final vacancy. Id. at 186. And John Foster Dulles and Tom Dewey removed themselves from consideration in 1953 when Chief Justice Fred Vinson died. Id. at 199; DeAn, supra note 17, at 12; Richard M. NiXON, RN: THE MEMOIRS Of RiCHARD NiXON, 419 (1978). Herbert Brownell, Dewey, Justice Potter Stewart and John Mitchell were among those who reportedly declined to be considered for chief justice in 1969. Conversation with Newsmen on the Nomination of the Chief Justice of the United States, Pub. Papers 393-394 (May 22, 1969); Stephen E. Ambrose, Nixon: The Triumph Of A Politician, 1962-1972, 274 (1989); NiXON, supra note 40, at 418-420. Powell removed himself for consideration for the nomination which went to Judge Clement Haynsworth. DEAN, supra note 17, at 16. Representative Richard Poff was Nixon's first choice for the appointments which ultimately went to Powell and Rehnquist; he withdrew for family reasons. $I d$. at 117-121 (explaining Poff's withdrawal to protect his son from learning he had been adopted). Clinton apparently would have appointed New York Governor Mario Cuomo to the vacancy created by the retirement of Justice Byron White in 1993. Cuomo, after avoiding Clinton's calls and then considering, and reconsidering, sent word that he was unavailable moments before Clinton was going to offer him the nomination. Taylor Branch, The Clinton Tapes: Wrestling History With The President 42-43 (2009); Bill Clinton, My Life 524 (2004); George Stephanopoulos, All Too Human: A Political Education 166-68, 170-74 (1999). Clinton also offered the nomination to Secretary of Education and former Governor Richard Riley. JEFFREY Toobin, THe Nine: InSIDE THE SeCret World of tHe Supreme CourT 76-77 (2008). A year later, Clinton's first choice was Senate Majority Leader George Mitchell but Mitchell declined Clinton's offer so as not to hurt the chances of passing health care legislation, CLINTON, at 592, and Clinton's chances for re-election. BRANCH, at 129. Miguel Estrada refused to be considered for the O'Connor and Rehnquist seats. JAN CRAWFORD GREENBURG, Supreme Conflict: The Insider Story of the StrugGle for Control of THE Supreme CourT 198, 248 (2007). Judge Maura Corrigan of the Michigan Supreme Court also reportedly refused to be considered for the O'Connor vacancy. Id. at 198.

${ }^{41}$ Justices Horace Lurton, Stanley Reed, Sherman Minton, Wiley Rutledge, Robert Jackson, Warren E. Burger, Robert Bork, Anthony Kennedy, David Souter, Stephen Breyer, Samuel J. Alito, and Elena Kagan were among the nominees who were passed over at least once. See NEMACHECK, supra note 5, at 147-55 (providing generally reliable short lists).
} 
Sixth, the pool of potential nominees has come from six occupational categories. Those considered and appointed are federal judges, state judges, federal appointed officers, high ranking elected officials, prominent lawyers or academics. These professional groups are by no means equal sources of Supreme Court prospects as Table C suggests.

\section{Table C Professions of Supreme Court Nominees When Selected}
1900-2011
1900-1955
$1956-2011$

Federal Judges

33

11

22

State Judges

5

3

2

Private Attorneys

8

6

2

Academics

2

2

0

Elected Office

5

5

0

Appointed Office

15

9

6

Federal judges are the most prolific source of Supreme Court nominees, especially recently. They provided $30 \%$ of the nominees during the first half of the period in question but $69 \%$ during the latter half and $80 \%$ of the nominees since $1968 .{ }^{43}$ Although the data for those considered is more obscure and less reliable, especially for the earlier periods, in this respect

\footnotetext{
${ }^{42}$ Lewis Schwellenbach, Elbert Tuttle, Edith Jones, Emilio Garza, and Diane Wood are among those considered, but passed over, on multiple occasions. See NeMACHECK, supra note 5, at 147-55 (providing generally reliable short lists).

${ }^{43}$ The exceptions since 1968 were Powell, Rehnquist (1971), O’Connor, Miers and Kagan. See Felix Frankfurter, The Supreme Court in the Mirror of Justices, 105 U. PA. L. REV. 781 (1957) (arguing against prior judicial experience as necessary qualification).
} 
those selected seem to reflect the short lists, too. ${ }^{44}$ Appointed federal officials have provided the second most frequent source of Court nominees, accounting for $22 \%$ of the total, although the figures differ during the two periods. During the first period, $25 \%$ of nominees were appointed officials, a category which provided almost as many nominees (9) as the federal bench (11). During the second half, $18 \%$ have been appointed officials. Harriet Miers and Elena Kagan were the only executive branch officials nominated to the Court in almost 40 years. ${ }^{45}$ State judges have provided $6 \%-8 \%$ of the nominees throughout the period although the most recent such appointee was O'Connor 30 years ago. ${ }^{46}$ Elected officials, a category which provided $14 \%$ of nominees during the first part of the period, have not provided a nominee since Governor Earl Warren in 1953 although Clinton offered nominations to Governor Mario Cuomo, former Governor (and Secretary of Education) Richard Riley and Senator George Mitchell ${ }^{47}$ and Nixon

\footnotetext{
${ }^{44}$ See generally NEMACHECK, supra note 5, at 147-55. Except for two close associates, Miers and Attorney General Alberto Gonzales, all of those George W. Bush seriously considered were federal judges. See id. at 154-55. President Obama's first shortlist of four reportedly included two federal judges; he chose Kagan from a short list which included at least three federal judges. President Clinton considered primarily federal judges although he also considered various elected politicians. See BRANCH, supra note 40, at 131; NEMACHECK, supra note 5, at 154; ToOBIN, supra note 40, at 75-82. Presidents Ford, Reagan and George H.W. Bush considered primarily federal judges although President Reagan expanded the pool for the O'Connor appointment and reportedly considered Senators Orrin Hatch and Howell Heflin when he nominated Robert Bork. NEMACHECK, supra note 5, at 152-54; YALOF, supra note 27, at 156-57; Gerald Boyd, Move to Right Seen, N.Y. TIMES, July 2, 1987, at A1.

${ }^{45}$ Prior to Miers, President Nixon nominated Assistant Attorney General William H. Rehnquist in 1971, President Johnson nominated Solicitor General Thurgood Marshall in 1967, President Kennedy nominated Deputy Attorney General Byron "Whizzer" White and Secretary of Labor Arthur Goldberg in 1962. President Truman nominated two members of his Cabinet - Secretary of Treasury Fred Vinson and Attorney General Tom Clark. Four of those Franklin Roosevelt nominated-Stanley Reed, William O. Douglas, Frank Murphy, and Robert Jackson-- served in the executive branch or, in one case, at an independent administrative agency.

${ }^{46}$ During the last 80 years, Presidents have nominated three state judges: Judge Benjamin Cardozo (1930), Judge William Brennan, Jr. (1956) and Judge Sandra Day O’Connor (1981). Most of Judge David Souter's judicial experience had been on New Hampshire state courts when President George H.W. Bush nominated him to the Court in 1990. Relatively few state judges have received serious consideration.

${ }^{47}$ Clinton, supra note 40, at 534, 592; John Maltese, The Selling of Supreme Court NomineEs 151-53 (1995); YALOF, supra note 27, at 197-205.
} 
offered a nomination to Senator Howard Baker in $1971 .{ }^{48}$ Similarly, practicing lawyers have declined as a source of nominees. Eight of those chosen since 1900 were private attorneys when nominated ${ }^{49}$ but Powell in 1971 was the last chosen and there is little evidence that many have recently received serious consideration. ${ }^{50}$ And academics comprise a tiny portion of the pool, with no sitting academic having been appointed since Franklin Roosevelt chose Frankfurter more than 70 years ago. ${ }^{51}$

These factors limit the period during which any individual is a viable candidate and introduce a large element of fortuity into the process. If being a federal judge is deemed an important credential, an otherwise distinguished lawyer may be passed over until confirmed for a lower court. The case of John Roberts is illustrative. Born in 1955, his years within the target age range of 47-62 are 2002 to 2017. The senate did not act on the first President Bush's nomination of Roberts to the United States Court of Appeals for the District of Columbia in 1992 and Roberts did not join that court until 2003 when nominated by the second Bush. Roberts's lack of a judicial credential would have substantially reduced his chances of selection had Supreme Court vacancies occurred early in Bush's first, rather than second, term. ${ }^{52}$ Roberts's

\footnotetext{
${ }^{48}$ DEAN, supra note $17,203-24$.

${ }^{49}$ Joseph Rucker Lamar, Brandeis, George Sutherland, Pierce Butler, Owen Roberts, Charles Evans Hughes (1930), Abe Fortas and Powell. Hughes and Sutherland, of course, had distinguished themselves through their public service and more properly belong in other categories.

${ }^{50}$ NEMACHECK, supra note 5, at 151-52 (listing Albert Jenner as considered by Johnson and Herschel Friday and William French Smith by Nixon).

${ }^{51}$ Kennedy seriously considered Harvard Professor Paul A. Freund in 1962 but no other law professors seem to have been serious candidates in recent decades. A number of former academics have been selected including Lurton, Harlan Fisk Stone, Douglas, Rutledge, Scalia, Bork, Douglas Ginsburg, Ruth Bader Ginsburg, Breyer, and Kagan.

${ }^{52}$ GreENBURG, supra note 40, at 242.
} 
nomination was contingent on factors such as Bush's contested election in 2000 and narrow reelection in 2004, Roberts's lower court confirmation in 2003, and the timing of the vacancies.

The pool from which a particular president selects is thus limited by a standard range of factors including party identification, age, and occupation. As suggested below, ideological and demographic factors may impose other filters which further narrow the pool of viable candidates. A president who assumes office after the other party has held the White House for eight years may find few federal judges in place who he regards as plausible nominees especially if a vacancy arises early in the term.

\section{The Context in Which the Choice is Made}

Presidential decision-making regarding Supreme Court vacancies does not occur in a vacuum. Presidents operate in a political context. A range of factors which are largely beyond their control present a web of opportunities and constraints. The context always is multidimensional and requires presidents to navigate a political terrain with markers which generally point in different directions. Presidents consider whether a nominee can be confirmed but they also respond to other concerns. Although the variables always differ, recurring factors include the following. ${ }^{53}$
A) The Senate

\footnotetext{
${ }^{53}$ See, e.g., Eisgruber, NeXt Justice supra note 3, at 125-29; LeE EpStein \& JeFFrey A. SEgAL, Advice AND Consent: The Politics of Judicial ApPointments 66, 70-71, 77-78 (2005) (mentioning qualifications, Senate composition, ABA recommendations); NEMACHECK, supra note 5, at 114-19, 130-32 (emphasizing Senate composition as check); YALOF, supra note 27, at 4-6 (mentioning timing of vacancy, Senate composition, public approval of president, attributes of outgoing justice, pool of candidates as constraints).
} 
Since the senate must advise and consent to any nomination as a prerequisite to appointment, its composition will constrain presidential nominations. Presidents must consider the senate's likely disposition to potential nominees or proceed at their peril.

The senate's party makeup is the most obvious variable. A president who faces a senate the opposing party controls (cross-party control) has less latitude than one who submits a nominee to a senate where his party holds a majority (unified government). Since 1900, several defeated nominations involved cross-party control. A Democratic senate (57 Democratic, 43 Republican) defeated Nixon's nominations of Haynsworth (45-55) and Carswell (45-51) and a Democratic senate (55 Democratic, 45 Republican) defeated Reagan's nomination of Bork (42$58)$.

Notwithstanding those episodes, since 1900 most nominations have succeeded in situations of cross-party senate control. Senates with Democratic majorities confirmed 12 nominations by Republican Presidents Eisenhower (Harlan, Brennan, Whittaker, and Stewart), Nixon (Burger, Blackmun, Powell and Rehnquist), Ford (Stevens), Reagan (Kennedy), and Bush (Souter, Thomas). Thus, $80 \%$ of the nominations involving cross-party control have been confirmed. ${ }^{54}$ Relatively few negative votes were cast against those successful cross-party nominees. ${ }^{55}$ Although presidents benefited from some degree of deference, that track record also traced to the president's willingness to offer nominees acceptable to a majority of senators.

\footnotetext{
${ }^{54}$ I have not included the withdrawal of the Douglas Ginsberg selection in this calculation. If it is included, it reduces the success rate to 12 of 16 or $75 \%$.

${ }^{55}$ Brennan, Whittaker, Blackmun, Stevens, and, Kennedy were confirmed unanimously, Powell with one adverse vote and Burger with three. The votes on the other nominations were: Harlan, 71-11; Stewart, 70-17; Rehnquist, 6826 and 65-33; Thomas, 52-48. Lee Epstein, Jeffery A. Segal, Harold J. Spaeth \& Thomas G. Walker, The Supreme Court Compendium: DATE, Decisions \& DeVElopments 357-58 (3d ed. 2003).
} 
Unified government may simplify the president's challenge but it does not guarantee a perfunctory, or even favorable, advice and consent process. A Republican senate rejected Judge John Parker in $1930 .{ }^{56}$ Johnson withdrew the Fortas-Thornberry nominations in 1968 after a majority Democratic senate failed to act when Republicans filibustered with support from southern Democrats. ${ }^{57}$ Bush had to withdraw the Miers nomination in 2005 even though his party controlled the senate. ${ }^{58}$

To be sure, the nominations which failed in unified government conditions involved somewhat different circumstances. Whereas the opposition party primarily prevented the FortasThornberry nominations (with help from southern Democrats), the president's own party forced Miers to withdraw. Yet the Parker, Fortas-Thornberry and Miers experiences suggest that a cooperative advice and consent process does not turn simply on which party controls the senate. $^{59}$

Nonetheless, the senate's party composition surely impacts presidential decision-making. A president with a cooperative senate may choose differently than one facing a less compliant body. Franklin Roosevelt was in a much stronger position in submitting Black and Reed to a

\footnotetext{
${ }^{56}$ ABRAHAM, supra note 4, at 32-33, 158.

${ }^{57}$ See, e.g., KALMAN, supra note 16, at 327-33 (1990); MARK Silverstein, Judicious Choices 28-32 (1994). Fortas's situation was made more precarious by Johnson's status as a lame duck president. See Keith E. Whittington, Presidents, Senates, and Failed Supreme Court Nominations 2006 SuP. CT. REV. 401, 418 (2006).

${ }^{58}$ GREENBURG, supra note 40, at 269-84; Stras \& Scott, supra note 1, at 1894.

${ }^{59}$ Cf. Whittington, supra note 57, at 436 ("Supreme Court appointments within unified government have become a presidential prerogative, requiring little consultation or consideration of senatorial interests. It requires a dramatic misstep (Miers) or a faltering party (Parker and Fortas) to lose a nominee to a same-party Senate."). Some other nominations under unified government conditions also received sizeable (i.e. more than ten) negative votes including Pitney (50-26), Brandeis (47-22), Hughes (52-26), Black (63-16), Minton (48-16), Marshall (69-11), Roberts (78-22), Alito (58-42), Sotomayor (68-31) and Kagan (63-37). Supreme Court Nominations, present-1789, UNITED STATES SENATE, http://www.senate.gov/pagelayout/reference/nominations/Nominations.htm.
} 
Senate with 76 Democrats and Frankfurter, Douglas and Murphy to one with 69 Democrats than was Ford, whose nominee had to win approval from a senate with 60 Democrats or George H.W. Bush, who faced a Senate with 55 Democrats. ${ }^{60}$ Those adverse numbers may have influenced Ford to favor Stevens in 1975 over more conservative options. Similarly, President George H.W. Bush may have seen Souter as more acceptable for the senate than alternatives who were more closely identified with the Reagan wing of the party. ${ }^{61}$

Of course, the president cannot assess the senate as a constraint by simply counting copartisans and cross-partisans. Even in a unified government context, the president must consider the loyalty of co-partisans, whether the other party is united and the intensity and size of possible opposition. A senate with 64 Democrats was insufficient to confirm Fortas and Thornberry because southern Democrats were not loyal and Republicans were united and willing to filibuster.

Sometimes simply winning confirmation is not sufficient for a president. One who seeks to unify the country or reflect strength or competence may seek a nominee likely to be confirmed with limited or no opposition. ${ }^{62}$ Alternatively, presidents may avoid a controversial, but

\footnotetext{
${ }^{60}$ See Party Division in the Senate, 1789-Present, United States SenATE, http://www.senate.gov/pagelayout/history/one item and teasers/partydiv.htm; see also Whittington, supra note 57, at 403 (arguing that scandal free, well-credentialed nominees generally are confirmed in unified government situations if their philosophies are in the mainstream of their party).

${ }^{61}$ GreEnBurg, supra note 40, at 97; TinsLey E. YARBrough \& DAVID HACKETT SOUTER: TRADITIONAL REPUBLICAN ON THE REHNQUIST COURT 104 (2005). The backing of influential Senator Warren Rudman also helped influence Bush. Rudman's lobbying had helped put Souter's name in play for the earlier seat which went to Anthony Kennedy. See Linda Greenhouse, A New Contender is Seen for Court, N.Y. TimES, Oct. 29, 1987, at A22.

${ }^{62}$ Conversation with Newsmen on the Nomination of the Chief Justice of the United States, PUB. PAPERS 391-392 (May 22, 1969) (explaining Nixon's nomination of Burger); YALOF, supra note 27, at 198 (explaining Clinton's nomination of Ginsburg); Gwen Ifill, Pragmatic Jurist, N.Y. TimES, May 14, 1994, at 1, 10 (explaining Clinton's nomination of Breyer).
} 
confirmable, choice to avoid antagonizing senators whose support is needed elsewhere. Any prospect Kennedy would nominate Judge William Hastie was hurt by the likelihood that the nomination of an African-American jurist would upset southerners whose cooperation Kennedy needed. ${ }^{63}$ President George H. W. Bush was anxious to avoid a divisive battle over a nominee to succeed Brennan to preserve capital for other pending challenges. ${ }^{64}$ Faced with an economic crisis and ambitious domestic agenda, Obama sought to avoid controversial candidates whose nominations would complicate achieving other goals.

The president may feel compelled to accommodate senate reactions to prior nominees. After Carswell's defeat, Nixon announced that he had concluded the senate would not confirm a southern strict constructionist so he would seek one from a different part of the country. ${ }^{65}$ Constrained by his need for a political victory, Nixon nominated Blackmun who satisfied his criteria and presumably would follow the lead of his close friend, Burger. ${ }^{66}$

Nearly two decades later, history repeated itself. After the senate defeated Reagan's nomination of Bork, 58-42, Reagan had to withdraw his choice of Judge Douglas Ginsburg

\footnotetext{
${ }^{63}$ YALOF, supra note 27 , at 78.

${ }^{64}$ GREENBURG, supra note 40, at 88; YALOF, supra note 27, at 191-192.

${ }^{65}$ Remarks to Reporters About Nominations to the Supreme Court, PUB. PAPERS 345 (April 9, 1970); see also Statement About Nominations to the Supreme Court, PUB. PAPERS 345-46 (April 9, 1970). Of course, Carswell's mediocrity and racist comments, not his origins, caused his defeat. See ABRAHAM, supra note 4, at 11-13; DEAN, supra note 17, at 18-23. Nixon's Chief of Staff, H.R. Bob Haldeman, wrote that Nixon was initially disposed to nominate Senator Robert Byrd (D.W.Va) following Carswell's defeat but that Haldeman suggested "that if it was obvious this Senate would not approve a Southerner, then put in a good Northern constructionist." H.R. Haldeman, The Haldeman Diaries: InSIDE THE NiXon White House 147 (1994).

${ }^{66}$ John Ehrlichman, Witness to Power: The Nixon Years, 129 (1982); see also Robert B. Semple, Jr., Judge Blackmun of Minnesota is Named to Supreme Court Seat by the President, N.Y. TIMES, Apr. 15, 1970, at 1, 34 (noting Blackmun's support by Mondale and Humphrey).
} 
following revelations of past drug use ${ }^{67}$ More moderate officials, like chief of staff Howard Baker, persuaded Reagan to nominate Judge Anthony Kennedy. ${ }^{68}$ "The experience of the last several months has made all of us a bit wiser," conceded Reagan in announcing Kennedy's nomination. Whereas Bork and Ginsburg had been depicted as strict constructionists, Reagan now suggested that "the mood and the time is now right for all Americans in this bicentennial year of the Constitution to join together in a bipartisan effort to fulfill our constitutional obligation of restoring the United States Supreme Court to full strength." ${ }^{69}$ Senate conservatives were upset but Reagan accepted "political reality" which included Democratic control of the senate and his weakened position. ${ }^{70}$

\section{B) Presidential Strength}

As suggested above, senate composition is not the only determinant of confirmability and confirmability is not the only political factor which influences presidential choice. A president's political strength or weakness may affect selection. Public opinion polls provide one measure. A president with high approval ratings is likely to be in a stronger position than one whose standing is precarious. Surely, Johnson was weakened in 1968 (his public approval rating

\footnotetext{
${ }^{67}$ Statement on the Withdrawal of the Supreme Court Nomination of Douglas H. Ginsburg, 2 PUB. PAPERS 1300 (November 7, 1987). Reagan first had to undergo an awkward media exchange in which the law and order President explained why he excused past drug use by his Supreme Court nominee. See Informal Exchange With Reporters on the Supreme Court Nomination of Douglas H. Ginsburg, 2 PUB. PAPERS 1292 (November 6, 1987); see also Remarks to Ethnic and Minority Administration Supporters on the Supreme Court Nomination of Douglas H. Ginsburg, 2 PUB. PAPERS 1294 (November 6, 1987).

${ }^{68}$ YALOF, supra note 27, at 2; see also Joel Brinkley, May Face a Fight, N.Y. TIMES, Oct. 30, 1987, at A1; Steven V. Roberts, Baker Seems to Be Vindicated, But the Cost is Proving High, N.Y. Times, Nov. 12, 1987, at A1.

${ }^{69}$ Remarks Announcing the Nomination of Anthony M. Kennedy To Be an Associate Justice of the Supreme Court of the United States, 2 PUB. PAPERS 1322 (November 11, 1987).

${ }^{70}$ Linda Greenhouse, Reagan Nominates Anthony Kennedy to Supreme Court, N.Y. TIMES, Nov. 12, 1987, at A1, B10.
} 
had fallen to around $40 \%$ ) when he nominated Fortas and Thornberry ${ }^{71}$ as was Reagan in 1987 when he named Bork. ${ }^{72}$ Yet robust ratings do not assure success and modest ones are not necessarily fatal. Nixon's approval ratings were around or above $60 \%$ when his nominations of Haynsworth and Carswell were defeated and about 50\% when Powell and Rehnquist were overwhelmingly approved. ${ }^{73}$

In addition to the public opinion scores, the trajectory of events and the way politicians perceive a president may affect selection. Reagan was much weakened in 1987 after the Democrats won control of the senate, his approval numbers declined, and the Iran-Contra debacle had tarnished his professional reputation. ${ }^{74}$ After Bork's nomination was rejected and that of Ginsburg withdrawn, Reagan recognized that his ability to win senate approval was significantly compromised.

Clinton's political vulnerability affected his choice of Judge Ruth Bader Ginsburg in 1993. Clinton could not afford another embarrassing defeat after the failed efforts to appoint Zoe Baird and Judge Kimba Wood as attorney general and Lani Guinier as assistant attorney general raised questions regarding his competence. "Sexy was good, but safe was better. We simply

\footnotetext{
${ }^{71}$ See Presidential Job Approval Center, GALLuP, June 26-July 1, 1968, http://www.gallup.com/poll/124922/Presidential-Job-Approval-Center.aspx.

${ }^{72}$ Interview with A.C. Culvahouse 51-52 (April 1, 2004) (transcript available at the Ronald Reagan Oral History Project). Reagan's approval ratings were in the high 40s but well below their measure before the Iran-Contra story became public the prior autumn. See Presidential Job Approval Center, GALLUP, http://www.gallup.com/poll/124922/Presidential-Job-Approval-Center.aspx.

${ }^{73}$ See Presidential Job Approval Center, GALLuP, http://www.gallup.com/poll/124922/Presidential-Job-ApprovalCenter.aspx.

${ }^{74}$ ABRAHAM, supra note 4, at 281-83; GREENBURG, supra note 40, at 47.
} 
couldn't afford another failed nomination," ${ }^{, 75}$ presidential adviser George Stephanopoulos later wrote. Clinton needed a smooth senate confirmation process to help establish presidential credentials. Clinton wanted to appoint Secretary of the Interior Bruce Babbitt but feared opposition from westerners upset over Babbitt's policies regarding grazing fees and mineral rights. Babbitt was deemed confirmable but the process would be costly. Babbitt's nomination would have added another vacancy to "an overloaded appointment process." Breyer, initially a leading candidate, had first paid social security taxes for a nanny belatedly after Justice White's retirement was announced. Clinton was not anxious to revisit a path which had cost him two nominees for attorney general. Ginsburg minimized the risk that the Clinton White House would be perceived as inept. ${ }^{76}$

The Miers nomination may have reflected Bush's feeling of political weakness. His poll ratings had declined and his administration was being criticized for mishandling the response to Hurricane Katrina. Some Democrats, including senate minority leader Harry Reid, had suggested Miers. ${ }^{77}$ Bush may have thought his weakened status counseled against choosing a movement conservative who would antagonize Democratic senators and interest groups. He misread the political context. Widespread conservative opposition to Miers made clear that the biggest threat came from alienating his base, not the Democratic minority. ${ }^{78}$

\footnotetext{
${ }^{75}$ StePHANOPOULOS, supra note 40, at 168.

${ }^{76} I d$. at 168-70; GREENBURG, supra note 40, at 167-70.

${ }^{77}$ Greenburg, supra note 40, at 30; Bush Picks White House Counsel for Supreme Court, CNN.cOM (Oct. 4, 2005), http://www.cnn.com/2005/POLITICS/10/03/scotus.miers/index.html.

${ }^{78}$ Greenburg, supra note 40, at 243-84; cf. Paul A. Freund, Appointment of Justices: Some Historical Perspectives, 101 HARV. L. REV. 1146, 1155 (1988) (arguing, based on Hoover's nomination of Cardozo, that weakened president can enhance standing by naming an eminent figure). See generally Whittington, supra note 57.
} 
The political calendar may also impose weakness. A president near the end of his service may find his powers diminished, ${ }^{79}$ particularly if party control of the White House seems precarious. Johnson experienced the classic perils of a lame duck nominator. Johnson had withdrawn from the presidential race and was unpopular when he nominated Fortas and Thornberry in June, 1968. Republicans sensed Nixon would be elected and southern Democrats saw Fortas as a symbol of their grievances against the Warren Court. Although senate minority leader Everett Dirksen had publicly praised the nominees, by nightfall on announcement day more than $50 \%$ of the 36 Republicans had publicly opposed Johnson appointing Warren's successor and others seemed likely to follow suit. ${ }^{80}$

\section{C) Political Commitments}

Campaign commitments sometimes limit presidential choice. Many presidential candidates make campaign promises regarding Court nominations. ${ }^{81}$ A president's past political statements create expectations which constrain behavior. A president ignores public commitments at his peril. Such behavior disappoints supporters and subjects the president's credibility to question.

Nixon pledged to appoint strict constructionists and law and order justices during his 1968 presidential campaign. ${ }^{82}$ He felt indebted to southern and border states for the nomination and the necessary electoral votes. Moreover, "the South had become an essential political base

79 Jeffrey A. Segal, Harold J. Spaeth \& SAra C. Benesh, The Supreme Court in the American LeGal SYSTEM 262, 267 (2005) (reporting poorer success ratio of nominations in fourth year of presidential term).

${ }^{80}$ Fred P. Graham, Johnson Appoints Fortas to Head Supreme Court; Thornberry to be Justice, N.Y. TIMES, June 27,1968 , at 1 .

${ }^{81}$ GERHARDT, supra note 21 , at 203-04.

${ }^{82}$ YALOF, supra note 27, at 97-98. 
to his reelection in 1972." ${ }^{83}$ This political context worked against appointing Herbert Brownell as chief justice since he was unacceptable to the south ${ }^{84}$ due to his advocacy of the Court's decision in Brown v. Board of Education. ${ }^{85}$ Ultimately, four of Nixon's six nominees came from the south or southwest. Nixon's second choice, Haynsworth, was calculated to please the south. 86 After Haynsworth's defeat, Nixon nominated Carswell, another southerner who had been a blatant segregationist. ${ }^{87}$ Nixon used Carswell's defeat to pander to the south. ${ }^{88}$ When two other vacancies presented themselves, Nixon nominated Powell of Virginia and Rehnquist of Arizona after considering other southerners. ${ }^{89}$

Reagan promised to appoint a woman to the Court during the 1980 campaign. In announcing O'Connor's selection, he acknowledged that commitment. ${ }^{90}$ In redeeming this pledge, Reagan angered some supporters who characterized O'Connor as pro-abortion. ${ }^{91}$

\footnotetext{
${ }^{83}$ DEAN, supra note 17 , at 15.

${ }^{84}$ AMBROSE, supra note 40, at 274; NIXON, supra note 40, at 419.

${ }^{85}$ Brown v. Bd. of Educ., 347 U.S. 487 (1954).

${ }^{86}$ EHRLiCHMAN, supra note 66, at 118 . ("This nomination would be the one to send a signal to every conservative and every Southerner; the nominee must be a bona fide son of the Old South."); see also AMBROSE, supra note 40, at 295-96; MELVIN SMALl, The PRESIDENCY OF RICHARD NiXON 166 (1999) ("Nixon offered the South more than symbolism with his attempt to appoint justices to the Supreme Court who would undo the alleged damage done to that region by the activist and liberal Warren Court.").

${ }^{87}$ Nixon aide Bryce Harlow advised Nixon that senators "think Carswell's a boob, a dummy. And what counter is there to that? He is." AMBRose, supra note 40, at 330. Senator Roman Hruska acknowledged that Carswell was mediocre but famously claimed Carswell could represent the millions of mediocre Americans, a pitch which failed to resonate.

${ }^{88}$ DEAN, supra note 17 , at $22-23$.

${ }^{89}$ NEMACHECK, supra note 5, at 151-52; YALOF, supra note 27, at 114-25.

${ }^{90}$ Remarks Announcing the Intention To Nominate Sandra Day O'Connor To Be an Associate Justice of the Supreme Court of the United States, PUB. PAPERS 596 (July 7, 1981) (admitting campaign "commitment that one of my first appointments to the Supreme Court vacancy would be the most qualified woman that I could possibly find.").
} 
Similarly, George W. Bush had repeatedly promised to name strict constructionists. The Republican conservative base sought to hold him to that commitment when Bush first considered Attorney General Alberto Gonzales, and then nominated Miers, to replace O'Connor.

Republican conservatives suspected either would stray from their principles and accordingly opposed their nominations. ${ }^{92}$

\section{D) Presidential Promises}

Presidential commitments may be personal as well as public. Presidents sometimes promise a Supreme Court seat. Whether they fulfill the pledge ultimately depends on a mix of factors including the force of competing considerations.

Harding joined the line of Republican presidents who promised Taft appointment as chief justice. ${ }^{93}$ He had also promised his friend, former Senator George Sutherland, the first open seat. When the first vacancy occurred upon the death of Chief Justice White, Harding resolved the dilemma by appointing Taft chief justice and naming Sutherland to the next vacancy. ${ }^{94}$

Eisenhower had promised to appoint Warren to the first Court vacancy when he was not able to place him in his cabinet. When Chief Justice Vinson's unexpected death made the center seat that opening, Eisenhower sought to redefine his promise as the first associate justiceship,

\footnotetext{
${ }^{91}$ Francis X. Clines, Baker Vows Support for Nominee, N.Y. TimeS, July 8, 1981, at A1.

${ }^{92}$ GREENBURG, supra note 40, at 247-84.

${ }^{93}$ MASON, William Howard TAFT, supra note 40, at 21, 27-32. McKinley promised Taft a seat on the Court and Theodore Roosevelt promised to name him Chief Justice.

${ }^{94}$ ABRAHAM, supra note 4, at 147-49. Franklin Roosevelt later promised Senate Majority leader Joseph T. Robinson a Supreme Court seat and Senate Democrats publicly endorsed him when Justice Van Devanter announced his retirement. Robinson died, however, while leading the fight on behalf of Roosevelt's Court packing plan, but before FDR acted on the vacancy. $I d$. at 166.
} 
considered some other candidates for chief justice, and instructed Attorney General Brownell to seek Warren's assent to that interpretation. Warren, insisted that the "first vacancy ... means the first vacancy"95 and Eisenhower nominated Warren rather than be seen as reneging on his commitment. $^{96}$

Some Presidents allow other considerations to override, or defer, fulfillment of their promises. Harding postponed his pledge to Sutherland and Eisenhower sought to narrow his to Warren. Truman had promised Secretary of Labor Lewis B. Schwellenbach that he would appoint him to the first Court vacancy ${ }^{97}$ but decided that he needed to appoint a Republican, thereby disqualifying Schwellenbach. John Kennedy had promised Arthur Goldberg strong

95 Jim Newton, Justice For All: EARl WARREN AND the NAtion He MADE 8-9 (2006); see also James Reston, Eisenhower Names Warren to be Chief Justice of U.S.; Rules Out Retail Sales Tax, N.Y. TIMES Oct. 1, 1953, at 1, 14 (reporting that Eisenhower did not have "an unbreakable commitment" to appoint Warren); National Affairs: Doubt in California, TIME, Sept. 14, 1953, at _ available at http:/www.time.com/time/magazine/article/0,9171,858232,00.html ("Warren wants a seat on the U.S. Supreme Court, probably can have the first one available, may get an interim appointment to some other job.”); National Affairs: Naming the 14th, TIME, Sept. 2, 1953, at _, available at http://www.time.com/time/magazine/article/0,9171,890626,00.html (describing Warren as “eagerly available”).

${ }^{96}$ Herbert Brownell with John P. Burke, Advising Ike: The Memoirs of AtTorney General Herbert BROWNELL, 166-68 (2007); NEWTON, supra note 95, at 9; YALOF, supra note 27, at 49-51. The Warren nomination engendered controversy because of Attorney General Brownell's decision to leak it to friendly reporters. See The Press: The Calculated Leak, TIME, Oct. 12, 1953, at _. When Eisenhower opened his press conference on September 30, 1953 by "confirming something that is certainly by no means news any more--that is, that I intend to designate Governor Earl Warren as Chief Justice of the United States" irate newsmen challenged the manner of disclosing the story. Raymond Brandt asked if "[i]t is going to be the policy of this administration to leak such important news to friendly newspapers?” The President's News Conference, PUB. PAPERS (September 30, 1953). The suggestion that Eisenhower promised Warren a spot on the Court in exchange for Warren's help in securing the 1952 nomination is myth. Although most of California's delegation had voted with Eisenhower on a rules challenge at the 1952 convention, Richard Nixon, not Warren, was primarily responsible for that action which irritated Warren. Warren hoped a deadlocked convention would turn to him and California gave him its unanimous support on the first ballot, refusing to switch even when an Eisenhower victory was apparent. The Supreme Court: One Law For All, TIME, Oct. 12, 1953, at _ ("Part of the press asserted, with an air of tolerant wisdom, that Eisenhower was paying a political debt incurred in the 1952 campaign. Actually, any debt that Ike owed Warren could have been paid by a third-class postmastership. At the G.O.P. convention in Chicago last year, Warren's California delegates did cast their votes for the Eisenhower side in the battle of the contested delegations, but that was the proper strategy for Candidate Warren, who was then hoping for a deadlock. When the balloting for President came, California voted for Warren and never switched. In the campaign, Warren made only late, routine efforts for Ike, and he conspicuously snubbed his fellow Californian, Richard Nixon.”).

${ }^{97}$ YALOF, supra note 27, at 22-23. 
consideration for a judicial vacancy. ${ }^{98}$ Kennedy did not wish to spare Goldberg's services as Secretary of Labor when Justice Charles Whittaker resigned in March, 1962 when a possible steel strike loomed but was willing to do so when Justice Frankfurter's retirement that summer created another vacancy after the strike threat had passed..$^{99}$

\section{E). Qualifications}

Presidents have multiple incentives to choose well-qualified nominees. Able people are likely to serve well and accordingly reflect well on the appointing president. Merit, of course, is often in the eye of the beholder and accordingly assessments regarding the qualifications of potential candidates are likely to be controversial. Yet presidential choice is constrained by the credentials of potential choices. Some literature confirms the common sense conclusion that the senate is less likely to reject candidates with gaudy resumes. ${ }^{100}$ An impressive nominee eliminates one argument against confirmation which might otherwise influence some and provide cover for others. Moreover, a president may enhance his image by a meritorious choice and hurt it if he chooses someone whose claim seems marginal. Accordingly, the qualifications, or lack thereof, of potential nominees may affect presidential decision. ${ }^{101}$

\footnotetext{
${ }^{98}$ KATZENBACH, supra note 18, at 58; YALOF, supra note 27, at 72-73; Oral History Interview by Anthony Lewis with Nicholas Katzenbach 71 (November 16, 1964) (transcript available in the John F. Kennedy Library Oral History Program). According to Robert Kennedy, however, Goldberg was not promised consideration for the Supreme Court but was promised appointment to a court of appeals at the appropriate time. See RoBert F. KenNedy In His Own Words: The UnPublished ReCollections of THE KenNedy YeARs 117 (Edwin O. Guthman \& Jeffrey Shulman eds., 1988).

${ }^{99}$ YALOF, supra note 27, at 73, 80-81.

${ }^{100}$ EPSTEIN \& SEGAL, supra note 53, at 69, 103, 114; Stras \& Scott, supra note 1, at 1898-1901; EPSTEIN ET AL, supra note 55, at 1173; SEGAL ET AL, supra note 79, at 265-66.

${ }^{101}$ ABRAHAM, supra note 4, at 35 .
} 
Some anecdotal evidence supports this intuitive judgment. Carswell's mediocrity was conceded even by his supporters ${ }^{102}$ and Miers clearly brought relatively modest credentials as even her handlers came to appreciate. ${ }^{103}$ Neither nomination succeeded and both reflected poorly on the presidents who made the selections. Similarly, Nixon determined he could not go forward with the nominations of Herschel Friday and Judge Mildred Lillie after the ABA judged them to be unimpressive candidates. ${ }^{104}$ Yet clearly merit is not the only relevant variable. Bork, Parker, Haynsworth, and Fortas were all able jurists yet were not confirmed. Brandeis was enormously qualified yet almost failed to receive committee approval.

Perceived merit may not guarantee confirmation yet it surely helps clear the way. The relationship of merit to confirmation and to presidential image makes it a contextual constraint which presidents ignore at their peril.

F). Timing; The Rest of the Agenda

The timing of a vacancy may affect a president's choice. The opportunity to make a Supreme Court nomination, though significant, never appears alone on the president's radar screen. Presidents often must consider the impact of a potential nominee on other priorities.

Truman's first vacancy occurred when Owen Roberts retired less than three months after Truman became president. Roberts's departure left the court with only one Republican at a time the new president faced major preoccupations - the Potsdam conference and threatened labor

\footnotetext{
102116 CONG. REC. 7498 (1970) (statement of Sen. Roman Hruska) (conceding Carswell was mediocre but arguing for representation of mediocre people); Id. at 7487 (statement of Sen. Russell Long) (arguing for confirmation of straight thinking B or C student).

${ }^{103}$ GREENBURG, supra note 40, at 266-68, 278-84.

${ }^{104}$ EHRLICHMAN, supra note 66, at 138; HALDEMAN, supra note 65, at 358, 366.
} 
strikes - as well as the need to foster an image as a legitimate national president. Those issues may have inclined Truman to name a Republican to help unify the nation and to win support for other initiatives. ${ }^{105}$ Kennedy could not risk antagonizing powerful senators by nominating Judge Hastie nor sacrifice Goldberg during the strike negotiations.

Electoral considerations may affect appointments on the eve of a presidential campaign. Although a coming election may have influenced Hoover and Ford to name "noncontroversial moderate[s]," Cardozo and Stevens respectively, ${ }^{106}$ on other occasions presidential politics pointed a president in a different direction. Theodore Roosevelt's 1903 appointment of William R. Day, who had been a close adviser to President McKinley, may have been Roosevelt's effort to curry favor with an important wing of the party. Some saw Taft's nomination of Mahlon Pitney, Chancellor of New Jersey, in February, 1912, as a move to help in his contest with Theodore Roosevelt for the Republican nomination. ${ }^{107}$

Woodrow Wilson's 1916 designation of Louis Brandeis was probably influenced by a need to unite progressive support behind the Democratic ticket. Wilson had won a three way race in 1912 when Taft and former President Theodore Roosevelt together attracted nearly 60\% of the vote. By 1916, it appeared unlikely that Roosevelt would compete against the Republican nominee and accordingly Wilson could not again expect a split to allow him to prevail with a minority vote. Democrats needed to attract new support and Wilson thought Brandeis could

\footnotetext{
${ }^{105}$ YALOF, supra note 27, at 21-25. Republican leaders called for Truman to name a Republican. See Urge Appointment of More GOP Judges, N.Y. TIMES, July 31, 1945, at 11. The appointment apparently upset Democrats, especially in Ohio, who found it would open the way for the election of conservative Republican John Bricker to the Senate. See James R. Reston, Bricker Looming for Senate in '46, N.Y. TIMES, Sept. 21, 1945, at 38.

${ }^{106}$ YALOF, supra note 27, at 4.

${ }^{107}$ Taft Names Pitney for Supreme Court, N.Y. TIMES, Feb. 20, 1912, at 5.
} 
appeal to Republican progressives. The Brandeis nomination was "the first public sign of [Wilson's] new departure," wrote his biographer, Arthur S. Link. The nomination was "an open defiance of and a personal affront to" big business and Taft supporters but it rallied Progressives to Wilson. ${ }^{108}$

Eisenhower weighed political factors in nominating Brennan in 1956, a presidential election year. Upon being notified in early September, 1956, of Justice Minton's plan to retire, Eisenhower instructed Brownell to look for a Catholic and a conservative Democrat as a replacement. Brennan was a Democrat, a Catholic and from New Jersey. ${ }^{109}$

These examples illustrate that the timing of a vacancy matters because of its interaction with other items on a president's agenda. Sometimes other matters take priority.

\section{G). Presidents' Past Conduct}

A president's past actions may also circumscribe options. Having justified his Courtpacking plan as a remedy for the shortcomings of judicial septuagenarians, ${ }^{110}$ Franklin Roosevelt could hardly select Judge Learned Hand for the Court in the 1940s since Hand was past 70. Theodore Roosevelt postponed naming his friend, William Moody, to the Court in 1902. Having recently named Holmes of Massachusetts, Roosevelt did not think he could name Moody, also of

\footnotetext{
${ }^{108}$ Arthur LinK, WoOdrow WiLson AND The Progressive ERA, 1910-1917 224-25 (1954).

${ }^{109}$ YALOF, supra note 27, at 57-61. At the time, there were only two Catholic federal judges under the age of 63 and every Catholic state supreme court judge was at least a decade older than Brennan who was 50. Brownell and his deputy, William Rogers, had heard Brennan speak a few years earlier at a conference and been impressed with his address.

110 John M. Ferren, Salt Of The Earth, Conscience of the Court: The Story Of Justice Wiley RutLedge, 217 (2004).
} 
Massachusetts, to the second vacancy (although he did appoint him to the third). ${ }^{111}$ Similarly, John Kennedy claimed he passed over Paul A. Freund for Whittaker's seat because he had already appointed too many Harvard men to high office. ${ }^{112}$

A president's prior Supreme Court selections also help shape the context of each new nomination. Unmet claims intensify demands the next time. By 1956, Eisenhower had twice failed to fill the "Catholic" seat, had named two Republicans to the Court and had elevated no state court judges. Minton's retirement provided an opportunity to address those issues, and Eisenhower achieved a trifecta by appointing Brennan, a Catholic, Democratic, state judge.

A predecessor's conduct may also shape the context. Eisenhower had criticized Roosevelt and Truman for appointing political or personal friends. After appointing Warren, Eisenhower stated a preference for those with prior judicial experience to demonstrate a commitment to merit over ideology or cronyism. ${ }^{113}$ Similarly, Nixon claimed that the controversy over Fortas's relationship with Johnson convinced him to avoid personal or political friends. ${ }^{114}$

H). Representation and Demography

Demographic characteristics have also constrained presidential action. Geography and religion were once most prominent; more recently, they have largely disappeared as criteria

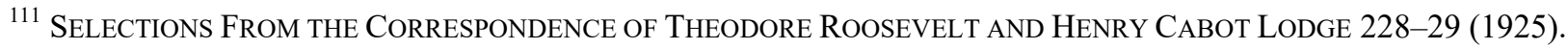

112 Arthur M. Schlesinger, JR., A Thousand Days: John F. Kennedy In the White House 698 (1965).

${ }^{113}$ EISGRUBer, NeXt JUSTICE, supra note 3, at 139; YALOF, supra note 27, at 43.

${ }^{114}$ Conversation With Newsmen on the Nomination of the Chief Justice of the United States, PUB. PAPERS 396 (May $22,1969)$. Contrary to Nixon's assurances of judicial independence, Nixon often spoke with Burger about subjects relocating to the Court's work; see EHRLICHMAN, supra note 66, at 133.
} 
while gender, race and ethnicity have emerged as more relevant diversity considerations. The particulars may change yet demography constrains presidential choice.

Presidents traditionally considered geographic balance, a practice which traced to the nineteenth century when justices rode circuit and when state or sectional identities loomed large. ${ }^{115}$ Oliver Wendell Holmes, Jr. of Massachusetts owed his appointment in part to the fortuity that Justice Horace Gray, also of Massachusetts, retired. Holmes's presence on the bench almost prevented Theodore Roosevelt from nominating Moody since he also came from Massachusetts. ${ }^{116}$ Hoover justified his nomination of Judge Parker since the Court of Appeals for the Fourth Circuit had not been represented on the Court for 70 years. ${ }^{117}$ Hoover questioned whether he could nominate Cardozo in 1932 since two New Yorkers-Charles Evans Hughes and Stone — were on the Court. ${ }^{118}$ Geography was deemed a sufficient constraint that Stone offered to resign to make way for Cardozo ${ }^{119}$ and the New York Times story reporting Cardozo's appointment proclaimed that geography had been "ignored."

\footnotetext{
${ }^{115}$ See Kurland, supra note 30, at 196-97.

${ }^{116}$ Moody is Nominated for Supreme Court, N.Y. TIMES, Nov. 8, 1906, at__.

${ }^{117}$ The President's News Conference, PUB. PAPERs 98-99 (March 21, 1930) (“Although fitness is, of course, the primary requisite for selection to the Supreme Court, it is interesting to note that that particular circuit has not been represented in the Court for 70 years. All the other circuits have been represented during the last 20 years except that circuit. The original setup of the Court was presumably, although not necessarily, based on a distribution amongst the different circuits, and at least this selection has the interesting point to it that it does meet the geographic question a little better than the selections hitherto proposed.").

${ }^{118}$ Alpheus Thomas Mason, Harlan Fiske Stone: Pillar of the Law, 335-36 (1956) (reporting Hoover inclined to avoid appointing another easterner); Drew PeArson \& Robert S. Allen, The Nine Old Men 217 (1936).

${ }^{119}$ AndREW KaUfMAn, CARDOZO 465 (1998); MASON, HARLAN FisK StONE, supra note 118, at 336.

${ }^{120}$ Cardozo is Named to Supreme Court; Nomination Hailed, N.Y.TIMES, Feb. 16, 1932, at 1.
} 
When Franklin Roosevelt met with Judge Wiley Rutledge, he exclaimed, "Wiley, you have a lot of geography!"121 Indeed, he did. Rutledge was born in Kentucky, raised there and in North Carolina and Tennessee, educated in Tennessee and Wisconsin, taught in public schools in Colorado, Indiana and New Mexico and at law schools in Colorado, Missouri and Iowa. ${ }^{122}$ Notwithstanding Rutledge's rich geographic pedigree, FDR deferred nominating him until his last vacancy.

Geography was not, however, an absolute constraint. Theodore Roosevelt ignored it in nominating Moody as Wilson did a decade later in selecting Brandeis. And Hoover named Cardozo even though two New Yorkers were already on the Court.

Nixon, who generally appointed southerners, was the last president to take geography seriously. It has more recently become irrelevant. Clinton considered Babbitt when the Court already had two members from Arizona (Rehnquist and O'Connor) and one from California (Kennedy). George W. Bush filled the vacancies created when Rehnquist died and O'Connor retired with federal judges sitting on the D.C. and Third Circuits respectively. The current Court includes four justices who served on the D.C. Circuit, one each from the First, Second, and Third Circuits, and Kagan from Massachusetts. Only Justice Kennedy had significant adult involvement with America west of the Mississippi River.

Religion was a factor during much of the twentieth century. Pierce Butler was recommended, and presumably appointed, in part because Harding thought the Court should

\footnotetext{
${ }^{121}$ FERREN, supra note 110 , at 219.

${ }^{122}$ ABRAHAM, supra note 4, at 186.
} 
have a Catholic member. ${ }^{123}$ Frank Murphy, also a Catholic succeeded Butler, and when Murphy died, some speculated that Truman would name another Catholic ${ }^{124}$ Truman, however, was annoyed at the Catholic hierarchy and was disinclined to perpetuate the Catholic seat. ${ }^{125}$ When he summoned Tom Clark and Senator J. Howard McGrath, both assumed he would name the Catholic McGrath to the Court. Truman surprised them with his intent to nominate Clark to the Court and McGrath as attorney general. ${ }^{126}$ Seven years later, Eisenhower restored the Catholic seat when he appointed Brennan, and the Court has always included at least one Catholic since then.

Brandeis became the first Jew to serve on the Court in 1916 and Cardozo joined him in 1930. The Cardozo seat became the "Jewish seat" and was held successively by Frankfurter, Goldberg and Fortas. Nixon, however, denounced the notion that a nominee should be appointed

${ }^{123}$ DANELSKI supra note 36 , at 86-87, 158-60.

124 The President's News Conference, PuB. PAPERs 394 (July 21, 1949) (“Q. Mr. President, I don't want to be impertinent--I don't even know whether it's an impertinent question--but will you follow the policy of replacing a Catholic with a Catholic? THE PRESIDENT. I have no comment on that.”).

125 The President's News Conference, PUB. PAPERS 404 (July 28, 1949); see also Oral History Interview by Jerry Hess with Matthew J. Connelly, Appointments Secretary to President Truman, in New York, N.Y., at 162-65, 35859 (Nov. 30, 1967) (transcript available in the Truman Presidential Library) (discussing pressure to appoint Catholic to replace Murphy).

126 The President's News Conference, PuB. PAPERs 403-04 (July 28, 1949); Harold Hinton, President Chooses Clark for the Supreme Court, M'Grath Attorney General, N.Y. TIMES, Jul. 29, 1949, at 1; The Judiciary: Death of a Scholar, TIME, Sept. 19, 1949, at_, available at http:/www.time.com/time/magazine/article/0,9171,800661,00.html. But see Oral History Interview by Jerry Hess with Tom C. Clark, in Washington, D.C., at 207 (Oct. 17, 1972) (transcript available in the Truman Presidential Library) ("Howard was pleased and I was pleased."). 
due to his religion ${ }^{127}$ although his view that Jews were too liberal and would not support him was his real motive. ${ }^{128}$

Religion has become less prominent as a reason for, or against, appointment. There was little, if any, discussion of religion as a reason to appoint Ginsburg, Breyer or Kagan and the fact that Chief Justice Roberts and Justices Scalia, Kennedy, Thomas, Alito and Sotomayor are Catholic did not apparently influence their selections. ${ }^{129}$

Nixon defended his decision to name two white men to the Court in 1971 on the grounds that a Court of only nine justices could not reflect every demographic group. ${ }^{130}$ Nixon's premise that a Court consisting of nine men (eight of whom were white) was demographically representative was under some assault in 1971 and is anachronistic today.

Race, gender, and ethnicity have recently emerged as significant demographic factors. Kennedy seriously considered naming Hastie in 1962 before Johnson nominated Thurgood Marshall five years later. Not coincidentally, the first President Bush nominated an AfricanAmerican, Thomas, to Marshall's seat.

Although Reagan's nomination of O'Connor represented the first of five women nominated for the Court, presidents began to consider gender diversity earlier. Nixon considered

\footnotetext{
${ }^{127}$ Conversation With Newsmen on the Nomination of the Chief Justice of the United States, PUB. PAPERS 391 (May 22, 1969).

${ }^{128}$ DEAN, supra note 17, at 147-48, 190. Nixon considered appointing Casper Weinberger whose name suggested he was Jewish although he was not. Id. at 41, 51-52.

${ }^{129}$ See, e.g., Barbara A. Perry, The Life and Death of the 'Catholic Seat' on the United States Supreme Court, 6 J.L. \& PoL. 55 (1989) (arguing that religion was relatively insignificant to Scalia and Kennedy nominations).

${ }^{130}$ Address to the Nation Announcing Intention To Nominate Lewis F. Powell, Jr., and William H. Rehnquist To Be Associate Justices of the Supreme Court of the United States, PUB. PAPERS 1054 (October 21, 1971).
} 
appointing a woman in 1971. ${ }^{131}$ Nixon opined on September 25, 1971 that "he really should go for a woman judge if we can get a good, tough conservative" since such a move would produce "tremendous political mileage."132 First Lady Pat Nixon engaged in "cogent and determined lobbying on every available occasion" for a woman justice ${ }^{133}$ and apparently was furious when Nixon named two men. ${ }^{134}$ Ford included Secretary of Housing and Urban Affairs Carla Hills and Judge Cornelia G. Kennedy on the list he submitted to the ABA. ${ }^{135}$ Reagan considered promoting O'Connor to chief justice. ${ }^{136}$ His successor, Bush, interviewed Judge Edith Jones when he named Souter. ${ }^{137}$ Clinton and George W. Bush nominated Ginsburg and Miers respectively. Obama's entire short list consisted of four eminently qualified women before choosing Sotomayor, and he considered several women (in addition to men) before choosing

${ }^{131}$ See Remarks at a Question-and-Answer Session With a 10-Member Panel of the Economic Club of Detroit, PUB. PAPERS 976 (September 23, 1971) ("I believe that a woman who is qualified should be appointed to any court-district court, circuit court, or Supreme Court. I have instructed the Attorney General, as he looks over the nominees that he is going to present to me, the recommendations, to be sure that qualified women are included if they meet the general standards that we have set."). Following this statement, though, Nixon spoke of the qualifications of the "men" he was looking for. Id.; see also NIXON, supra note 40, at 423; The President's News Conference, PuB. PAPERS 1034-35 (October 12, 1971). But see DEAN, supra note 17, at 113 (Nixon stating that he did not believe "a woman should be in any government job whatever" because "they are erratic. And emotional.").

${ }^{132}$ EHRLICHMAN, supra note 66, at 134 (Nixon told Ehrlichman "he would appoint a woman if Mitchell could find him one.”); HALDEMAN, supra note 65 , at 358.

${ }^{133}$ AmBrose, supra note 40, at 469; EHRLICHMAN, supra note 66, at 134; NIXON, supra note 40, at 423.

${ }^{134}$ AMBROSE, supra note 40, at 469; HALDEMAN, supra note 65, at 367-68.

${ }^{135}$ Lesley Oelsner, Ford Chooses a Chicagoan for Supreme Court Seat; Nominee is Appeals Judge, N.Y. TIMES, Nov. 29, 1975, at 1. In addition, Jimmy Carter has said he would have appointed Secretary of Education (and former federal judge) Shirley Hufstedler but no vacancies occurred during his term. JOAN BISKUPIC, SANDRA DAY

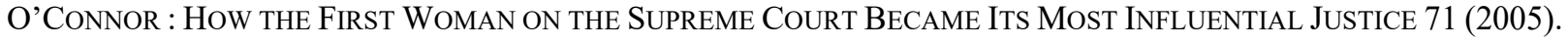

${ }^{136}$ YALOF, supra note 27, at 148-55.

${ }^{137}$ GREENBURG, supra note 40, at 96-97. 
Kagan. Similarly, Obama's three predecessors considered, but passed over, prospective Hispanic nominees. ${ }^{138}$

\section{I.) The Seat Being Vacated}

Presidents face constraints based upon the characteristics of the justice in the vacated seat. These considerations may relate to stature, demography, or ideology. Holmes's retirement prompted the suggestion that his eminence required a successor of great distinction. As Andrew Kaufman put it, "a giant should be replaced by a giant," a formula which favored Cardozo. ${ }^{139}$ Roberts's retirement in 1945 put greater pressure on Truman to name a Republican than would have been the case had Murphy or Rutledge left.

The ideological characteristics of the departing justice may also influence the choice of a successor. Although Reagan initially nominated Bork, a conservative ideologue, to replace Powell, the Court's swing vote, after Bork's defeat he eventually chose Kennedy, whose philosophy was more nuanced. Yet George W. Bush nominated conservative jurists John Roberts and ultimately Alito to replace O'Connor, the swing vote of the Rehnquist Court.

Bush's response to the O'Connor vacancy also suggests that presidents have not always felt totally confined by demographic claims to particular seats. He nominated two men and only one woman to replace O'Connor, the first, and, at the time, one of only two, women justices. Similarly, Wilson appointed Brandeis to replace Lamar, a Georgian, even though only two justices came from the south and Brandeis's Kentucky ties were somewhat attenuated after more

\footnotetext{
${ }^{138}$ Elisabeth Bumiller, Longtime Adviser, N.Y. TIMES, Oct. 4, 2005, at A1, A23; Ifill, supra note 62, at A1, A10.

${ }^{139}$ KAUfMAN, supra note 119, at 461, 464-67; see also PEARSON \& ALLEN, supra note 118, at 217-18 (reporting that Senator Borah, among other senators, pressed Hoover to appoint Cardozo and threatened to defeat any other nominations).
} 
than three decades in Boston, a city which already claimed Holmes. ${ }^{140}$ Harding felt compelled to maintain the Catholic seat yet Truman did not. Roosevelt perpetuated a Jewish seat, as did Kennedy and Johnson, but Nixon did not.

J). Campaigns for the Court

Campaigns for Supreme Court seats constitute part of the context which confronts a president. Perhaps no figure campaigned more vigorously for the Court than did Taft. ${ }^{141}$ His quest apparently began when he was a young state court judge in Ohio and continued through discussions with Presidents McKinley and Theodore Roosevelt by which time Taft's ambitions had fixed on the center seat. ${ }^{142}$ Even after the conservative Taft lost the presidency to Wilson, a progressive Democrat, Taft apparently hoped Wilson would name him to the Court. ${ }^{143}$ Taft's campaign continued after Harding's election in 1920 as Taft and his friends lobbied Harding and his associates to appoint the former president chief justice. ${ }^{144}$ Taft's former Secretary of War Jacob M. Dickinson visited Chief Justice White to discuss White's retirement and Taft asked White's physician about the Chief Justice's health. ${ }^{145}$ After White died in May, 1921, Taft

\footnotetext{
${ }^{140}$ TODD, supra note 40, at 29-32.

141 See generally MASON, WILlIAM HoWARD TAFT, supra note 40, at 17-33; TODD, supra note 40, at 23-29.

${ }^{142}$ Mason, William HowARD TAFT, supra note 40, at 27, 30.

${ }^{143} I d$. at $17-33$; TODD, supra note 40 , at 23-29.

${ }^{144}$ Mason, WILliam HowARD TAFT, supra note 40, at 77-78.

${ }^{145} I d$. at 80 .
} 
associates pressed Attorney General Daugherty to persuade Harding to name Taft, and Harding soon agreed to do so. ${ }^{146}$

Although Frankfurter portrayed his appointment as a surprise, ${ }^{147}$ his friends campaigned vigorously on his behalf, writing to senators of Frankfurter's merit and disparaging potential rivals. Senator George Norris endorsed Frankfurter as did important New Dealers like Harry Hopkins, Henry Ickes and Robert Jackson; Justice Stone, along with Jackson, urged that Frankfurter could counterbalance Chief Justice Hughes. ${ }^{148}$

Following Vinson's death, Warren and his associates worked to advance his prospects for the seat which he believed Eisenhower had promised him. Concerned that some would push for a Catholic justice, Warren and his colleagues contacted members of the Church hierarchy to seek their support. Warren also contacted influential friends in both parties. ${ }^{149}$

Burger assiduously courted Nixon at the beginning of his term. Ehrlichman wrote that Burger "wanted a seat on the Supreme Court so passionately that he would have agreed to almost anything to get it." ${ }^{\prime 150}$ Burger asked Brownell to approach Nixon on his behalf. ${ }^{151}$ When Burger

\footnotetext{
${ }^{146}$ DANELSKI, supra note 36, at 28-33; MASON, WILLIAM HOWARD TAFT, supra note 40, at 81 . Once president, Taft was the target of a campaign by his old friend, Judge Horace Lurton, for appointment to the Court. MALTESE, supra note 47, at 47; John P. Frank, Supreme Court Justice Appointments: II, 1941 WIS. L. REV. 343, 373-75 (1941).

${ }^{147}$ Felix Frankfurter ReminisCes 278-82 (Harlan B. Phillips ed. 1960).

${ }^{148}$ H.N. Hirsch, The Enigma OF Felix FranKfurter 124-26 (1981); Michael E. PARrish, Felix FranKfurter AND His TIMES: THE REFORM YEARS 275-78 (1982).

149 NewTon, supra note 95, at 3, 8 (2006).

${ }^{150}$ EhrLichmAN, supra note 66, at 114; see also DEAN, supra note 17, at 14 (quoting Mitchell that Burger had campaigned to be Chief Justice).

${ }^{151}$ YALOF, supra note 27, at 101-04.
} 
came to the White House to swear in some presidential appointees, he brought a speech he had given on law and order. Thereafter, he frequently sent Ehrlichman notes and articles. Burger not only persuaded Nixon and Mitchell of his commitment to law and order and to undoing parts of the Warren Court's jurisprudence, he also said he would resign as Chief Justice before Nixon left office so Nixon could appoint his successor. ${ }^{152}$

Campaigns occur against candidates, too. Jackson's detractors worked to deny him elevation to chief justice. ${ }^{153}$ Some in the Reagan justice department worked to derail Kennedy’s nomination, telling conservative senators that Reagan was deciding between Kennedy and that senator's favorite candidate. The strategy apparently induced some "Anybody but Kennedy" calls to the White House. ${ }^{154}$

On one occasion, Hoover's choice of Cardozo in 1932, a nomination followed widespread and apparently spontaneous clamor for a selection without the prospective beneficiary's involvement. Cardozo's admirers mounted a full-scale effort which overcame a number of demographic obstacles. ${ }^{155}$

\footnotetext{
${ }^{152}$ EHRLICHMAN, supra note 66, at 114-15. Christopher Eisgruber points out that judges wage quiet campaigns, too, by relying on well-placed law clerks and by cultivating administration insiders. See EISGRUBER, NEXT JUSTICE, supra note 3, at 140. Ruth Bader Ginsburg's prospects were advanced by the efforts of her husband, Martin Ginsburg, a distinguished tax professor, who engaged friends, including Senator Daniel Patrick Moynihan to lobby Clinton on her behalf. See GERHARDT, supra note 21, at 194; YALOF, supra note 27, at 200.

${ }^{153}$ See YODER, supra note 30, at 4-6, 9-23, 37-41.

${ }^{154}$ Greenburg, supra note 40, at 58; Norman Viera \& LeONARd Gross, Supreme Court Appointments: JudGe Bork AND the PolitiCizATION OF SENATE CONFiRmations 183 (1998) (stating three conservative Senators threatened to oppose Kennedy).

${ }^{155}$ KaUfman, supra note 119, at 461-69; LAURENCE H. TriBe, God SAVE This HonOrable CourT: How the Choice of Supreme Court Justices Shapes Our History 80-81 (1985); Cardozo is Named to Supreme Court; Nomination Hailed, N.Y. TIMES, Feb. 16, 1932, at 1.
} 
Whether the vacancy is publicly known affects a president's freedom of action. Although vacancies created by death will be apparent, some justices have provided presidents with advance notice of their retirement, allowing the president to limit unwanted advice by suppressing news of the vacancy.

Kennedy, for instance, allowed little time to elapse between the public disclosure of a vacancy and his selections. News of Whittaker's resignation did not leak until March 29, 1962 at which point the administration had known of it for several weeks. ${ }^{156}$ Kennedy revealed his choice of White the following day. ${ }^{157}$ Kennedy announced Frankfurter's retirement and Goldberg's nomination simultaneously, both of which were apparently known to few administration officials. ${ }^{158}$ The secrecy prevented outsiders from advocating favored candidates. McGeorge Bundy later observed that "one of the things I admire about Bobby [Kennedy] is that when it came to Supreme Court appointments he always kept the very existence of the vacancy so tight that nobody else had a chance to get their advice in except Sorensen and me in a couple of cases, and our advice never got taken." ${ }^{159}$ Similarly, Stewart and Burger gave the Reagan administration advance notice of their retirements, allowing it to pursue a replacement without public discussion. By contrast, Holmes's retirement triggered lobbying on different sides. ${ }^{160}$

\footnotetext{
${ }^{156}$ Dennis J. Hutchinson, The Man Who Once Was Whizzer White : A Portrait of Justice Byron R. White 311-12 (1998); Anthony Lewis, Ailing Justice Whittaker Leaving Supreme Court, N.Y. TIMES, March 30, 1962, at 1; Katzenbach Oral History Interview, supra note 98, at 55.

${ }^{157}$ Anthony Lewis, Byron White Gets Whittaker's Seat on Supreme Court, N.Y. TIMES, March 31, 1962, at 1.

${ }^{158}$ Anthony Lewis, Justice Frankfurter Retires; Kennedy Hails 23-Year Service, Names Goldberg as Successor, N.Y. TimeS, Aug. 30, 1962, at 1, 14.

${ }^{159}$ Interview of McGeorge Bundy 127-28 (March, 1964) (transcript available at JFK \#1 Kennedy Library Oral History Project).

${ }^{160}$ KAUFMAN, supra note 119 , at 461-67.
} 


\section{K). Concluding Words on Contextual Constraints}

The foregoing discussion suggests a range of contextual factors shape selection of Supreme Court nominees. The constitutional allocation of power gives the president an advantage. The senate may reject, but cannot dictate, the choice. The president may submit a second and a third name. The senate may find it difficult to continue deflecting presidential nominees. ${ }^{161}$ Even so, the process imposes costs on the president. Defeats may harm his public prestige or professional standing, alienate those whose help he may need in other battles, and divert resources from other priorities. Senate composition is an important, but not the only, contextual, influence. Presidents also consider the message the choice conveys about them and its impact on a range of objectives. Past commitments, whether political, or personal, constrain choice. So, too, do strategic considerations geared towards other priorities or future campaigns.

\section{The Influence of Presidential Idiosyncrasy}

Ultimately, one person makes each Supreme Court nomination. And, as presidential scholar Fred I. Greenstein has pointed out, "the matter of who occupies the nation's highest office can have profound repercussions." 162 The personality, preferences, values and decisionmaking style of that individual inevitably affect the outcome.

Presidents seek to choose ideologically compatible justices but the evidence does not support the suggestion that absent a confirmation constraint they choose the option who is

\footnotetext{
${ }^{161}$ Michael Comiskey, Seeking Justices: The Judging OF Supreme COURT NomineEs 10 (2004) (describing presidential discretion in choice compared to senate's reactive role); Orrin G. Hatch, The Politics of Picking Judges, 6 J.L. \& POL. 35, 50-51 (1989) (describing Senate role as secondary); see also Stras \& Scott, supra note 1, at 1895 (describing other presidential weapons including use of bully pulpit, recess appointments and logrolling).

${ }^{162}$ Fred I. Greenstein, The Presidential Difference: LeAdership Style From FDR to Clinton 2 (2000).
} 
philosophically closest. ${ }^{163}$ It seems implausible, for instance, that Reagan chose Rehnquist, Scalia and Bork in that order because that ranking matched their ideological similarity to him.

Similarly, the president's party identification is clearly one, but by no means the only, significant variable. McKinley had pledged to appoint Boston lawyer, Alfred Hemenway, to Justice Gray's seat when it became vacant but McKinley's vice president, Theodore Roosevelt, appointed Holmes instead. ${ }^{164}$ Roosevelt passed over Lurton in 1906 but three years later Roosevelt's chosen successor, Taft, nominated his former colleague. ${ }^{165}$ Truman selected Minton who Franklin Roosevelt had disappointed. Truman knew of Roosevelt's promise to make Jackson chief justice but appointed Vinson. Lyndon Johnson certainly would not have selected White and Kennedy would not have chosen Fortas or Thornberry. George H.W. Bush selected Souter after Reagan did not.

In each case the president drew from a different pool and acted in a different context. But each president also brought a different mix of experience, commitments, biases, values and outlooks, had different biographical baggage, made decisions differently and listened to different advisors. Each Supreme Court nomination is a personal decision which reflects the approach of the president who makes it. In short, it matters who is president.

A). Policy Objectives and Judicial Philosophy

\footnotetext{
${ }^{163}$ See NEMACHECK, supra note 5, at 127.

${ }^{164}$ Liva Baker, The Justice From Beacon Hill: The Life and Times of Oliver Wendell Holmes 339 (1991); SHeldon M. Novick, Honorable Justice: The Life OF Oliver Wendell Holmes 233 (1989).

${ }^{165}$ Frank, supra note 146, at 373-76.
} 
Presidents typically use Court appointments to advance immediate policy objectives. ${ }^{166}$ These goals will vary depending on party identification, worldview and a host of other factors. Taft had different objectives than did Theodore Roosevelt, Truman than FDR, Johnson than Kennedy, Bush than Reagan. In part, the different contexts in which they acted affected the saliency of particular issues and positions. Yet these pairs also saw the world differently and occupied different places on the political spectrum notwithstanding their shared partisan identification.

It is not surprising that presidents weigh short-term policy considerations in making nominations. ${ }^{167}$ Presidents have greater stakes regarding decisions the Court might render during their term(s) as opposed to those handed down in future decades. Moreover, they generally can more accurately predict topics on the Court's immediate docket than in the more remote future.

Theodore Roosevelt delayed appointing Holmes until reassured of his attitudes. ${ }^{168}$ Franklin Roosevelt sought justices who would not use restrictive interpretations of the Commerce and Due Process Clauses to strike down New Deal legislation; all nine of his nominees subscribed to doctrines which would accomplish Roosevelt's desired ends. ${ }^{169}$ Nixon

\footnotetext{
${ }^{166}$ See, e.g., Abraham, supra note 4, at 3; Thomas E. Cronin \& Michael A. Genovese, The Paradoxes of the AMERICAN PRESIDENCY 227 (1998); EISGRUBER, NeXt Justice, supra note 3, at 126-29; NEMACHECK, supra note 5, at 131-32; Erwin Chemerinsky, Ideology and the Selection of Federal Judge, 36 U.C. DAVIS L. REV. 619, 624 (2003) (arguing that presidents always consider ideology).

${ }^{167}$ See, e.g., Kurland, supra note 30, at 199 ("The choice, therefore, is usually made in the only way it can reasonably be made, in terms of the one or two dominant issues of the day likely to come to judicial attention.”).

${ }^{168}$ BAKER, supra note 164, at 342-49; NOVICK, supra note 164, at 234-36; I SELECTIONS FROM THE CORRESPONDENCE OF THEODORE ROOSEVELT AND HENRY CABOt Lodge, 519, 1884-1918, (1925) (Roosevelt asking Lodge if "Judge Holmes was in entire sympathy with our views.").

${ }^{169}$ ABRAHAM, supra note 4, at 166.
} 
sought nominees sympathetic to his law and order agenda and against busing. ${ }^{170}$ George W. Bush weighed the views of prospective candidates regarding presidential power. ${ }^{171}$

The broader judicial philosophy of prospective nominees also influences some presidents. ${ }^{172}$ Not surprisingly, Democratic and Republican presidents seek justices with a different orientation. Theodore Roosevelt wanted to appoint justices who followed Alexander Hamilton and John Marshall, not Thomas Jefferson and John L. Calhoun. ${ }^{173}$ Eisenhower cited Warren's "middle of the road philosophy" as an important criterion. ${ }^{174}$ Nixon wanted justices who shared his "strict constructionist" disposition, particularly a prospective nominee's views on law and order, ${ }^{175}$ a formulation Nixon used four times in an eight paragraph statement of criteria for Court nominees. ${ }^{176}$ The "strict construction" nomenclature returned when George W. Bush

\footnotetext{
${ }^{170}$ YALOF, supra note 27 , at 97-98.

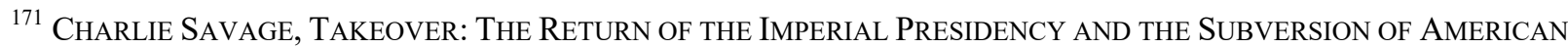
DEMOCRACY, 250-78 (2007).
}

${ }^{172}$ See, e.g., Gary J. Simpson, Mired in the Confirmation Mess, 143 U. PA. L. REV. 1035, 1043 (1995) ("Presidents are so able to put people to their ideological liking on the Court that the line separating the executive and judicial branches can become dangerously blurred.").

${ }^{173}$ II RoOSEVELT-LODGE, supra note 168, at 231.

174 The President's News Conference, PUB. PAPERS 618-19 (September 30, 1953) ("From the very beginning, from the moment of the unfortunate death of my great friend, Mr. Vinson, I have been thinking over this whole thing. I certainly wanted a man whose reputation for integrity, honesty, middle-of-the-road philosophy, experience in Government, experience in the law, were all such as to convince the United States that here was a man who had no ends to serve except the United States, and nothing else. Naturally, I wanted a man who was healthy, strong, who had not had any serious illnesses, and who was relatively young--if you can call a man of approximately my age relatively young--relatively young with respect to some others that I was thinking of. On balance, to my mind he is a man who will make a great Chief Justice; and so I selected him.”).

175 Conversation With Newsmen on the Nomination of the Chief Justice of the United States, PUB. PAPERS 392 (May 22, 1969); The President's News Conference, PuB. PAPERs 39 (January 30, 1970).

${ }^{176}$ Remarks to Reporters About Nominations to the Supreme Court, PUB. PAPERS 345 (April 9, 1970); see also Remarks in Fort Wayne, Indiana, PuB. PAPERS 917 (October 20, 1970); Radio Address on Crime and Drug Abuse, PUB. PAPERS 984-85 (October 15,1972) ("I will continue to apply the criteria of strict constructionism and regard for the public safety in making appointments to the Supreme Court and other Federal courts.”). 
announced that "I don't believe in liberal activist judges. I believe in strict constructionists."177 Bush later praised Roberts, Miers and Alito as such. ${ }^{178}$

Not surprisingly, recent Democratic presidents have articulated different philosophical concerns. When White's retirement in 1993 created his first vacancy, Clinton said that in addition to ability and experience he wanted someone with knowledge of "the problems of real people, and someone with a big heart."179 A few days later, he said that "I would like to put someone on the Court who would make sure that there was a certain balance in the debate, that there was a real feeling for the rights of ordinary Americans under the Constitution, but that also someone who was hard-headed, who understood that the criminal law had to be enforced, that you didn't want to over-legalize the country. There's a nice balance to be formed. ${ }^{180}$ Obama, famously and controversially, suggested his nominees should be empathetic among other qualities. $^{181}$

\footnotetext{
${ }^{177}$ Presidential Debate in Boston (October 3, 2000) (transcript available with the American Presidency Project). Gore, by contrast, promised to avoid litmus tests but said "in my view, the Constitution ought to be interpreted as a document that grows with our country and our history." See also Remarks and a Question-and-Answer Session at the American Society of Newspaper Editors Convention, 1 PUB. PAPERS 368 (April 5, 2001) ("We're going to pick the most qualified people we can find, people that share my philosophy about strict constructionism on the Court."); Remarks at a Fundraiser for Senatorial Candidate Saxby Chambliss in Atlanta, I PUB. PAPERS 518 (March 27, 2002) (“And I'm going to put strict constructionists on the bench."); Presidential Debate in St. Louis, Missouri, III PUB. PAPERS 2416 (October 8, 2004) (“And so I would pick people that would be strict constructionists. We've got plenty of lawmakers in Washington, DC. Legislators make law. Judges interpret the Constitution.”).

${ }^{178}$ Remarks in a Discussion on Senior Security in Atlanta, II PUB. PAPERs 1266 (July 22, 2005); The President's News Conference, II PUB. PAPERS 1504, 1505 (October 4,2005); President George W. Bush, Remarks at a Reception for Senatorial Candidate Mark Kennedy, in Minneapolis, Minnesota (December 9, 2005).

${ }^{179}$ Exchange With Reporters in Atlanta, I PUB. PAPERS 325 (March 19, 1993).

${ }^{180}$ Interview With Dan Rather of CBS News, I PUB. PAPERS 353 (March 24, 1993).

${ }^{181}$ President Barrack Obama, Remarks on the Retirement of Supreme Court Justice David Souter (May 1, 2009) (transcript available with the American Presidency Project).
} 
Judicial philosophy seemed less critical for some other presidents. ${ }^{182}$ Truman and Kennedy each had a relatively free hand regarding their nominations but neither focused on judicial philosophy. Although they knew those they appointed, there is no indication that they had any deep understanding of their judicial outlooks. And some presidents appointed justices who they might have predicted would be dissimilar. Wilson appointed two progressive jurists, Brandeis and Clarke, after naming McReynolds, one of the most reactionary members of the Court. Wilson may not have anticipated the course of McReynold's jurisprudence, but he surely could have discovered that McReynolds and Brandeis were very different people. ${ }^{183}$

Although four Reagan choices - Rehnquist, Scalia, Bork and Ginsburg - reflected the president's stated brand of conservatism, his first and final nominees were less ideological. Those involved in President Reagan's search had warnings that O'Connor and Kennedy might not toe a strict conservative line on abortion and privacy issues. ${ }^{184}$ Reagan may have felt constrained to name Kennedy after the unsuccessful Bork and Ginsburg nominations but his administration did not apply the same philosophical standards to O'Connor as to his other choices.

Different presidents attach varying importance to Supreme Court nominations. Their divergent views may affect their selection conduct. For Franklin Roosevelt (especially early on),

\footnotetext{
${ }^{182}$ Chemerinsky, supra note 166, at 624 (arguing that ideology matters more to some presidents than to others).

${ }^{183}$ See, e.g., ABRAHAM, supra note 4, at 139-40. Wilson may have nominated the incorrigible McReynolds to remove him from the Cabinet. McReynolds was disliked by his colleagues who greeted his departure with "general relief." LINK, supra note 108, at 28. In 1971, Nixon briefly considered reprising the same strategy, naming Spiro T Agnew to the Court to create a vice-presidential vacancy which he could then fill with John Connally. Ultimately, Nixon concluded that the Democratic Senate would attack him through Agnew, thereby damaging both. DEAN, supra note 17, at 39-40; EHRLICHMAN, supra note 66, at 36.

${ }^{184}$ YALOF, supra note 27, at 2, 210-11 n.4.
} 
Nixon, Reagan and George W. Bush, the composition of the Court heavily impacted policy areas of critical importance to them or their supporters. Their choices were generally designed to further those objectives to the extent possible. Others, such as Truman or Kennedy, assigned less weight to the work of the Court. Their relative indifference reflected a combination of personal disposition and the press of other business. ${ }^{185}$ Truman, Kennedy, Ford, the first Bush, Clinton and Obama sometimes acted as if they did not want Court nominations to interfere with other objectives. Katzenbach, for instance, said that Kennedy took his two Supreme Court nominations "very seriously" but that the President did not regard the Court as "a really co-equal branch" and accordingly did not view Court appointments as seriously as he might have done. ${ }^{186}$

\section{B) Friends}

Some Presidents were disposed to nominate personal or political friends, either to reward past service or with the expectation that friends will discharge judicial functions as the president would like. Theodore Roosevelt offered his third vacancy to Taft, his former Attorney General Philander Knox, and Secretary of State Elihu Root before Moody accepted. ${ }^{187}$ Friendship apparently inspired Taft to appoint Lurton. Harding named his close friend, Sutherland, ${ }^{188}$ and Coolidge nominated his attorney general, and Amherst contemporary, Stone. Franklin Roosevelt had close relationships with virtually all of his nominees. Black and Byrnes were senate supporters, Reed, Douglas, Murphy and Jackson served in his administration, and Frankfurter was a close, external adviser.

\footnotetext{
${ }^{185}$ See, e.g., YALOF, supra note 27, at 21 (calling Truman "already apathetic about judicial matters" and facing Potsdam Conference, labor unrest and postwar reconversion).

${ }^{186}$ Katzenbach Oral History Interview, supra note 98, at 77.

187 ABRAHAM, supra note 4, at 129.

${ }^{188}$ Justice Clarke Out of Supreme Court; To Work for League, N.Y. TIMES, Sept. 5, 1922, at 1.
} 
Truman, however, provided the poster example of a president inclined to cronyism in his appointments. His nominees-Burton, Vinson, Clark and Minton --were close friends. He had served in the senate with Burton and Minton and played poker with Cabinet members Vinson and Clark.

Similarly, Kennedy appointed two officials from his administration, White and Goldberg, and passed over one eminently qualified potential justice, Freund, who had declined a high administration position. ${ }^{189}$ Johnson nominated his close friend, Fortas, twice, another Texas crony, Thornberry, and Solicitor General Marshall.

Conversely sometimes presidents do not appoint insiders to keep them in the administration. Harding did not wish to lose Secretary of State Hughes when White died ${ }^{190}$ and Hoover may have passed over Mitchell to retain him in the cabinet. ${ }^{191}$ Truman ruled out Undersecretary of War Robert Patterson because the senate was investigating war time procurements, a matter within Patterson's portfolio. ${ }^{192}$ Kennedy was not prepared to lose Goldberg when Whittaker resigned. ${ }^{193}$

Other Presidents have thought it bad practice to appoint close associates. Eisenhower implicitly, and Nixon explicitly, distanced themselves from their predecessors' practice of

\footnotetext{
${ }^{189}$ KATZENBACH, supra note 18, at 59, 63 (attributing nominations of White and Goldberg to identification with Kennedy, not views); see also ROBERT F. KENNEDY In His Own WORDS, supra note 98, at 117 ("Paul Freund, for instance, was asked to come down and be Solicitor general — and he turned it down. And that was a factor obviously: When President Kennedy wanted him, he didn't want to do it.").

${ }^{190}$ Ex-President Taft Succeeds White as Chief Justice, N.Y. TimES, July 1, 1921, at 1, 13.

${ }^{191}$ KAUFMAN, supra note 119 , at 466-67.

${ }^{192}$ See The President's News Conference, PUB. PAPERS 311 (September 6, 1945) (denying report he would name Patterson to Court); YALOF, supra note 27, at 24-25.

${ }^{193}$ Katzenbach Oral History Interview, supra note 98, at 57-58, 71-72.
} 
choosing friends and insiders. Judge Richard Arnold's Arkansas ties may have worked against his selection by Clinton. Arnold was a jurist of rare distinction but Clinton, having been criticized for appointing some Arkansas associates, may have been reluctant to elevate Arnold even though they were not close friends. ${ }^{194}$

\section{C) Firsts}

Some presidents seek to make historic nominations. Like a path-breaking vicepresidential nomination, such a selection may send positive messages about the president while enhancing his legacy. Johnson wanted to appoint the first African-American justice and orchestrated events to produce that result. He persuaded Marshall to leave the federal judiciary to become solicitor general to enhance his resume. He engineered a Court vacancy by moving Attorney General Katzenbach to undersecretary of state, identifying Deputy Attorney General Ramsey Clark as Katzenbach's likely successor, and confirming with Clark's father, Justice Clark, that his son's promotion would trigger his resignation. ${ }^{195}$

\footnotetext{
${ }^{194}$ BRANCH, supra note 40, at 150-52. Arnold's health-he suffered from lymphoma-also weighed against him. Id. at 150-52; ClinTON, supra note 40, at 592.

${ }^{195}$ KATZENBACH, supra note 18, at 212-13 ("It was not so much that Dean Rusk approved of me, which I did not doubt, but the fact that LBJ would gain another appointment to the Court" that led to these moves). As choreographed, Johnson's announcement of Ramsey Clark's promotion on February 28, 1967 brought the resignation of $b$ Justice Clark, and the nomination of Marshall to fill the vacancy on June 13, 1967. Although there was some discussion of others, Johnson "always returned to Marshall as his first choice for the vacant seat." YALOF, supra note 27, at 89; see also Remarks to the Press Announcing the Nomination of Thurgood Marshall as Associate Justice of the Supreme Court, 1 PUB. PAPERS 611 (June 13, 1967) ("I believe he earned that appointment; he deserves the appointment. He is best qualified by training and by very valuable service to the country. I believe it is the right thing to do, the right time to do it, the right man and the right place.").
} 
Having made a campaign commitment to appoint a woman, Reagan named O'Connor to the first vacancy. Reagan was proud to appoint the first woman justice ${ }^{196}$ and labeled her confirmation as "historic."197 Reagan later was drawn to Scalia in part because of his Italian heritage. Reagan was so anxious to nominate the first Italian-American justice that he ignored arguments that it would be prudent to nominate the controversial Bork in 1986 while Reagan still had a Republican majority in the Senate. ${ }^{198}$ Before Obama nominated the first Hispanic to the Court, other presidents gave serious consideration to doing so. ${ }^{199}$

D) Sending a Message

Presidents often use a Supreme Court nomination to send a message about who they are and what they value. Katzenbach recognized this aspect when he suggested that Kennedy's first

\footnotetext{
${ }^{196}$ See, e.g., Remarks in Denver, Colorado, at the Biennial Convention of the National Federation of Republican Women, PUB. PAPERS 811 (September 18, 1981) (“Of course, one accomplishment that I'm especially proud of as President is the appointment to the Supreme Court of Sandra O'Connor. [Applause] Thank you. Thank you very much. She is an outstanding example of the qualified women living all across this country whose talents and energies are so helpful in Washington."); Remarks at a White House Luncheon for the Governors' Representatives to the Fifty States Project for Women, PUB. PAPERS 901(October 7, 1981). Reagan insisted that he would not name a woman "merely to do so" a step which "would not be fair to women nor to future generations of all Americans whose lives are so deeply affected by decisions of the Court." His commitment was "to appoint a woman who meets the very high standards that I demand of all court appointees. I have identified such a person." Remarks Announcing the Intention To Nominate Sandra Day O'Connor To Be an Associate Justice of the Supreme Court of the United States, PUB. PAPERS 596 (July 7, 1981).

${ }^{197}$ Statement on Senate Confirmation of Sandra Day O'Connor as an Associate Justice of the Supreme Court of the United States, PUB. PAPERS 819 (September 21, 1981) ("This truly is a happy and historic day for America. Judge O'Connor's judicial philosophy is one of restraint. ...Let me also say that Judge O'Connor's confirmation symbolizes the richness of opportunity that still abides in America — opportunity that permits persons of any sex, age, or race, from every section and every walk of life to aspire and achieve in a manner never before even dreamed about in human history.").

${ }^{198}$ Interview with Peter Wallison 57-59 (October 28-29, 2003) (transcript available at the Ronald Reagan Oral History Project, Miller Center, University of Virginia http://web1.millercenter.org/poh/transcripts/ohp_2003_1028_wallison.pdf); GREENBURG, supra note 40, at 46-47 (describing ordering of Scalia, then Bork a "strategic blunder").

${ }^{199}$ GREENBURG, supra note 40, at 188 (reporting Bush (43) desire to appoint Gonzales); Maureen Dowd, Bush's Best Man, N.Y. TIMES, July 2, 1991, at A1 (reporting consideration by Bush (41) of Judge Emilo Garza).
} 
nominee especially should be someone "closely identified" with the president. ${ }^{200}$ Choosing a "first" is one way a president can tie the administration to the American Dream, particularly if the nominee's life story presents a compelling narrative. Presidents like Johnson, Reagan and Obama associated themselves with that concept through their appointments of Marshall, O'Connor and Sotomayor respectively. Obama concluded his announcement of Sotomayor's nomination by underscoring this point: ${ }^{201}$

Well, Sonia, what you've shown in your life is that it doesn't matter where you come from, what you look like, or what challenges life throws your way, no dream is beyond reach in the United States of America.

And when Sonia Sotomayor ascends those marble steps to assume her seat on the highest court in the land, America will have taken another important step towards realizing the ideal that is etched above its entrance: Equal justice under the law.

Presidents use nominations to associate themselves with other values. Harding, Franklin Roosevelt, Truman and Eisenhower each hoped a cross-party selection would foster their image of bipartisanship. Wilson emphasized his progressive credentials through his 1916 nominations of Brandeis especially and Clarke. Nixon used his judicial nominations to identify with law and order themes; Hoover and George W. Bush connected themselves to excellence through their appointments of Cardozo and Roberts. Clinton hoped to show competence by choosing nominees who would win easy confirmation. The messages vary, but presidents invariably use Supreme

\footnotetext{
${ }^{200}$ Katzenbach Oral History Interview, supra note 98, at 63.

${ }^{201}$ President Barack Obama, Remarks on the Nomination of Sonia Sotomayor To Be a Supreme Court Associate Justice (May 26, 2009), in the American Presidency Project. President Obama's press secretary, Robert Gibbs, said that Judge Sotomayor's outstanding qualifications were her experience, her approach to judging and "the President believes that her life story is a compelling one.” Press Briefing by Press Secretary Robert Gibbs (May 26, 2009), in AMERICAN PRESIDENCY PROJECT, available at http://www.presidency.ucsb.edu/ws/index.php?pid=86235\&st=sotomayor\&st $1=$.
} 
Court nominations to sound themes helpful to their presidency or to avoid those which are detrimental.

\section{E) Presidential Requirements}

In addition to the inevitable recitation of the quality of prospective candidates as a central factor, ${ }^{202}$ presidents also impose distinct criteria which channel their choices. Presidents have viewed the age of prospective nominees differently. Taft advocated appointing younger justices, a profile which fit four of his six appointees-Hughes (48), Van Devanter (51), Lamar (53) and Pitney (54)-- but made exceptions to appoint his close friend, Lurton (65) and to elevate White (65) as Chief Justice, which, as will be suggested, may have had other appeal to Taft. Eisenhower imposed a 62 year old limit with some flexibility. ${ }^{203}$ Nixon wanted to appoint justices likely to serve at least ten years. He said that apart from Rehnquist's "unquestioned legal qualifications and his moderately conservative philosophy" his "most attractive attribute was his age" (47). ${ }^{204}$ That John Roberts was a decade younger than Judge J. Harvie Wilkinson worked in his favor. ${ }^{205}$ Those Clinton considered were in the 55 to 60 range.

Some Presidents have expressed, or acted upon, a preference for appointing sitting federal judges. Taft, Eisenhower, Nixon, Ford, Reagan, and both Bushes thought this experience highly relevant. Others generally avoided judges-Franklin Roosevelt and Kennedy, for

\footnotetext{
${ }^{202}$ See, e.g., The President's News Conference, 2 PUB. PAPERS 1869 (November 14, 1975) (Ford claiming he was looking for "best person - the best person qualified"); Exchange with Reports Aboard Air Force One, PUB. PAPERS 735 (June 28, 1991) (Bush emphasizing "excellence" and "representation of all Americans" and "best qualified candidate" for Justice Marshall's seat).

${ }^{203}$ Dwight D. Eisenhower, The White House Years: Mandate For Change 1953-1956 227 (1963).

${ }^{204}$ NIXON, supra note 40, at 424. Nixon suggested Rehnquist might serve 25 years; he served 34 years.

${ }^{205}$ GREENBURG, supra note 40, at 187, 201.
} 
instance — or suggested that the Court needed other experience. George H.W. Bush emphasized Souter's long experience on the state bench. ${ }^{206}$ Clinton wanted to appoint a politician and George W. Bush suggested that Miers's lack of judicial background was an advantage. ${ }^{207}$

F) Presidential Personality

Presidents are human beings and accordingly their unique personalities affect their decisions. ${ }^{208}$ It is not simply that psychology influences a president's choice of friends and advisors, that John Kennedy was friendly with White and relied on his brother, Robert Kennedy, whereas Lyndon Johnson was drawn to Fortas and despised RFK. Personality also affects how presidents react to different people, whether they are combative or conciliatory, whether they feel bound by promises, how intensely they engage in the process.

Harding was a compliant person who was susceptible to the influence of Taft, who he greatly admired, and Daugherty. ${ }^{209}$ They could shape his Court nominations. By contrast, Franklin Roosevelt knew his choice of Black would upset some senators who resented Black's strong support for Roosevelt's court packing plan. That anticipated reaction apparently appealed

\footnotetext{
${ }^{206}$ Remarks Announcing the nomination of David Souter to be Associate Justice of the Supreme Court of the United States and a Question-and-Answer Session with Reports, 2 PUB. PAPERS 1047 (July 23, 1990).

${ }^{207}$ The President's News Conference, PUB. PAPERs 1506 (October 4, 2005).

${ }^{208}$ JAMEs DAVID BARBer, THe PREsidential CHARACTER 5-7 ( $2 \mathrm{~d}$ ed. 1977).

${ }^{209}$ DANELSKI, supra note 36, at 167-79.
} 
to Roosevelt. ${ }^{210}$ Reagan knew Bork would draw opposition, yet was confident he could sway senators to support the ill-fated choice. ${ }^{211}$ Other presidents were more conflict-averse.

Whether consciously or not, presidents sometimes look for justices who fit their selfperception. Nixon praised Burger as someone who received his education the "hard way." "He went to law school at night and worked during the daytime, but he made a brilliant academic record." 212 Those words could have appeared in Nixon's own biography. George H. W. Bush may have been drawn to Souter, who shared his Ivy League education and New England upbringing.

Clinton did not set out to name a woman when he nominated Ginsburg but ultimately concluded that she was his best available choice. When they met, he was particularly drawn to her, ${ }^{213}$ his earlier meeting with Breyer having not gone well. A year later, Clinton was more disposed to Breyer. ${ }^{214}$

H). Leadership Style; Participants and Persuaders

A president's decision-making style may impact selection. ${ }^{215}$ Eisenhower, Reagan and George W. Bush delegated extensive authority. They generally allowed subordinates great

\footnotetext{
${ }^{210}$ John P. Frank, Mr. Justice BlaCk: THE MAN AND His OPIniOns 98 (1949).

${ }^{211}$ Interview with Howard Baker 5-6 (Aug. 24, 2004) (transcript available in the Ronald Reagan Oral History Project, Washington, D.C.).

${ }^{212}$ Remarks Announcing the Nomination of Judge Warren Earl Burger To Be Chief Justice of the United States, PUB. PAPERS 388-89 (May 21, 1969).

${ }^{213}$ CLINTON, supra note 40, at 524.

${ }^{214}$ Id. at 524-25, 592; YALOF, supra note 27, at 200-01.

${ }^{215}$ See, e.g., GREENSTEIN, supra note 162, at 195-97 (listing organizational capacity as among criteria of presidential performance).
} 
latitude to shape their options. By contrast, Franklin Roosevelt, Truman, Johnson, Clinton and Obama became more personally involved, although in different ways. Roosevelt, Truman, and Johnson knew those they nominated quite well. Clinton did not, but he involved himself heavily in the process, insisting on additional names and devoting considerable time to meeting with prospective nominees. ${ }^{216}$

How a president organizes the search and who, if anyone, has his ear matters. Some presidents have relied on the justice department or attorney general. Others assign responsibility to the White House staff, especially the counsel, and at times the vice president and chief of staff. Some consult with important senators or justices. Some keep their own counsel. Some presidents encourage public discussion to vet candidates and test reactions. And some combine the various models. The nature of, and participants in, the process, and their relative influence structure the president's options and influence his decision.

Johnson made selections without much consultation, and often ignored advice he did receive. Johnson asked Katzenbach to generate a list of potential replacements for Goldberg after appointing him Ambassador to the United Nations, but Katzenbach thought the exercise a waste of time since he was convinced from the outset Johnson would choose Fortas. ${ }^{217}$

Johnson's approach worked when he had a compliant senate but it helped produce the Fortas-Thornberry debacle. Johnson conceived the plan to nominate Fortas as chief justice and

\footnotetext{
${ }^{216}$ YALOF, supra note 27, at 196-205.

${ }^{217} I d$. at 82-83 (quoting Katzenbach and reporting that Johnson told Fortas he planned to nominate him before asking Katzenbach to prepare a list).
} 
the obscure ${ }^{218}$ Thornberry to Fortas' seat shortly after learning of Warren's plan to retire. ${ }^{219}$ Johnson said he had conferred with the senate and anticipated no problem, ${ }^{220}$ but his consultations were a charade. After Republican minority leader Dirksen suggested several names the very day Johnson received Warren's letter, Johnson raised Fortas as a possibility and secured Dirksen's qualified support. ${ }^{221}$ But Senator James Eastland, chairman of the senate judiciary committee, advised against Fortas. ${ }^{222}$ He promised to let the nomination come out of committee but told Johnson it would be "terribly unpopular" and would not be confirmed. ${ }^{223}$ Leading

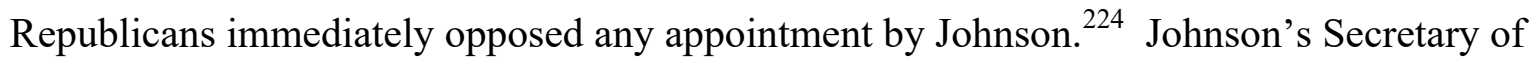
Defense Clark Clifford warned Johnson that the Republicans might oppose the Fortas-

\footnotetext{
${ }^{218}$ The President's News Conference, 1 PUB. PAPERS 747 (June 26, 1968) (reporting that first question at the press conference announcing their nominations was "Judge Thornberry's first name?").

${ }^{219}$ Earl Warren Oral History Interview by Joe Frantz with President Lyndon B. Johnson 21 (Sept. 21, 1971) (transcript available in the LBJ Library, available at http://www.lbjlib.utexas.edu/johnson/archives.hom/oralhistory.hom/Warren-E/Warren-e.PDF) (stating that Johnson asked his view of Fortas as his successor when Warren disclosed his plans).

${ }^{220}$ The President's News Conference, 1 PUB. PAPERs 747-48 (June 26, 1968).

${ }^{221}$ Oral History Interview II by Joe B. Frantz with Everett McKinley Dirksen (March 21, 1969) (transcript available in the LBJ Library, available at http://www.lbjlib.utexas.edu/johnson/archives.hom/oralhistory.hom/DirksenE/dirksen2.pdf).

${ }^{222}$ Oral History Interview by Joe B. Frantz with James O. Eastland (February 19, 1971) (transcript available in the LBJ Library, available at http://www.lbjlib.utexas.edu/johnson/archives.hom/oralhistory.hom/Eastland/Eastland.pdf).

${ }^{223} I d$. at 14 .

${ }^{224}$ Fred P. Graham, Warren to Leave Court; Some in G.O.P. Open Flight to Bar a Succession in 68, N.Y. TIMES, June 22, 1968, at A1; Marjorie Hunter, Senate Coalition May Block Action on Warren's Post, N.Y. TIMES, June 23, 1968 , at A1.
} 
Thornberry tandem and unsuccessfully urged Johnson to appoint a Republican to Fortas's seat. ${ }^{225}$ Johnson's failure to engage in meaningful soundings cost him the appointment.

In earlier times the attorney general often influenced the selection either due to his close relationship to the president or, during the first half of the twentieth century, from lack of alternative capacity in the White House. Eisenhower's attorneys generals played the leading role in the nominations of Brownell's close friend, John Marshall Harlan II, ${ }^{226}$ of Brennan ${ }^{227}$ and of Potter Stewart. ${ }^{28}$ Nixon relied on Mitchell, his former law partner and campaign manager, to identify nominees for the first two vacancies ${ }^{229}$ but involved others after the HaynsworthCarswell defeats. Ford listened to Attorney General Edward Levi who gave Stevens his highest praise. ${ }^{230}$ And Attorney General William French Smith played the crucial role in selecting O'Connor for the first vacancy. Smith and his associates generated the initial list of, and reports on, candidates and Smith lobbied for O'Connor for more than a month before Reagan chose her. ${ }^{231}$ Although Reagan involved his White House chief of staff and counsel in subsequent

${ }^{225}$ Clark Clifford with Richard Holbrooke, Counsel to the President 555-56 (1991); Kalman, supra note 16 , at $327-28$.

${ }^{226}$ Brownell, supra note 96, at 179; Tinsley E. YARBrough, John MARSHALl Harlan: GrEAT DisSenter of THE WARREN COURT 80, 87 (1992); see NEMACHECK, supra note 5, at 83-85 (reporting that Franklin Roosevelt relied on Attorney General Homer Cummings for initial appointments).

${ }^{227}$ BROWNELL, supra note 96, at 180.

${ }^{228}$ YALOF, supra note 27, at 63-67 (describing advocacy efforts of Attorney General William Rogers).

${ }^{229}$ Conversation With Newsmen on the Nomination of the Chief Justice of the United States, PUB. PAPERS 393 (May 22, 1969). Nixon claimed Mitchell was the only person he discussed the initial appointment with in any detail and pointedly noted that Vice President Agnew, Warren, Dewey and Brownell were informed after the decision was made.

${ }^{230}$ David M. O'Brien, The Politics of Professionalism: President Gerald R. Ford's Appointment of Justice John Pail Stevens, 21 PRES. STUD. Q. 103-26 (1991).

${ }^{231}$ William French Smith, LaW And Justice in the Reagan Administration: The Memoirs of an Attorney GENERAL 63-68 (1991); YALOF, supra note 27, at 135-41. 
nominations, the Justice Department also played a critical role in the decisions to nominate Rehnquist, Scalia, Bork and Ginsburg. ${ }^{232}$

The unique role of the attorney general in structuring options and influencing decisions was particularly evident during the Kennedy administration when Whittaker retired. John and Robert Kennedy initially turned to Byron White, deputy attorney general, for guidance, a natural move in view of White's official position and service as law clerk to Chief Justice Vinson. White involved his friend and subordinate, Katzenbach, who gave Hastie's work measured reviews $^{233}$ and, in White's absence from Washington, included White on the list sent to President Kennedy. White was selected. ${ }^{234}$ Robert Kennedy's relationship with his brother helped prevent Freund's appointment. Freund enjoyed considerable support among important advisers including White House counsel Theodore C. Sorensen, Bundy, and Clifford; ${ }^{235}$ Katzenbach also thought highly of Freund. ${ }^{236}$ But Robert Kennedy opposed Freund who had declined appointment as Solicitor General. ${ }^{237}$

\footnotetext{
${ }^{232}$ DAVid G. SAVAge, Turning Right: The MAKING of the Rehnquist Supreme Court 9, 15-18, 137, 167-69, 176-78 (1992); YALOF, supra note 27, at 155-64.

${ }^{233}$ HutChinson, supra note 156, at 314 (reporting that Katzenbach was "clearly unimpressed" with Hastie's opinions); KATZENBACH, supra note 18, at 57; Katzenbach Oral History Interview, supra note 98, at 65 (stating he reported that Hastie was "'competent and pedestrian.'”).

${ }^{234}$ HUTCHINSON, supra note 156, at 312-22; KATZENBACH, supra note 18, at 58-59.

${ }^{235}$ CLIFFORD, supra note 225, at 375; HUTCHINSON, supra note 156, at 319-20.

${ }^{236}$ KATZENBACH, supra note 18, at 57-59 (expressing Katzenbach's high opinion of Freund but concern about appointing another Harvard faculty member).

${ }^{237}$ ROBERT F. KENNEDY In HIS OWN WORDS, supra note 98, at 117.
} 
The more recent institutionalization of the White House staff, especially a large counsel's office, has shifted the dominant role there. ${ }^{238}$ The change began during the Nixon administration when, following the Haynsworth and Carswell vetting failures, Nixon ran a parallel process from the White House and ultimately rejected Mitchell's suggestions. ${ }^{239}$ When Nixon's search for successors to Black and Harlan floundered, the intervention of various White House aides on behalf of Rehnquist proved critical. ${ }^{240}$ Clinton's process was also run from the White House as Attorney General Janet Reno played little apparent role. ${ }^{241}$ Clinton received input from a wide range of people in a process which no one or few associates dominated.

Many recent presidents have relied on a hybrid process with input from the justice department and the White House staff. The search for a successor to Justice Powell is illustrative. The White House received about 24 hours notice of Powell's decision to retire. At a hastily convened Oval Office meeting including Chief of Staff Howard Baker, White House counsel A.B. Culvahouse and justice department representatives, Reagan directed that Bork, who had

\footnotetext{
${ }^{238}$ NEMACHECK, supra note 5, at 105-06; NIXON, supra note 40, at 423-24; YALOF, supra note 27, at 115-25. Although they are based on her review of original records at presidential libraries, I question some of Nemacheck's conclusions regarding the extent to which the White House and Justice Department influenced the decision. She views the Haynsworth and Carswell nominations as being shared enterprise whereas the bulk of the materials suggest that the Justice Department, especially Mitchell, was most influential. She views Kennedy's nomination of White as also being a shared process; although Sorensen and Bundy weighed in, it seems clear that Robert Kennedy and Katzenbach played pivotal roles. Finally, she credits the Fortas nominations to the Justice Department. I think it clear that Johnson dominated the process. Regarding the first Fortas nomination, Katzenbach has said his role was perfunctory. See NEMACHECK, supra note 5, at 96-99.

${ }^{239}$ AMBrose, supra note 40, at 468-69; EHRLiCHMAN, supra note 66, at 137-38.

${ }^{240}$ DEAN, supra note 17 , at 226-33.

${ }^{241}$ YALOF, supra note 27, at 196-202; cf. Remarks on the Resignation of Supreme Court Justice Harry A. Blackmun and an Exchange With Reporters, 1 Pub. Papers 599 (April 6, 1994) (including Reno as part of process); Press Briefing by Lloyd Cutler, Special Counsel to the President (April 6, 1994), in AMERICAN PresidenCy ProjeCt, available at $\mathrm{http}: / / \mathrm{www}$. presidency.ucsb.edu/ws/index.php?pid=59792\&st=supreme + court\&st1 $=($ excluding Reno).
} 
been "a close second" for Scalia's seat, be included on the list. ${ }^{242}$ Reagan was clearly "leaning toward Bork" but others pushed for Kennedy or Judge Laurence Silberman; Senator Rudman lobbied for Souter. Many in the administration thought it Bork's turn, a view Reagan shared. ${ }^{243}$ He understood Bork might face opposition yet was confident he could persuade senators to support him. ${ }^{244}$ Not anticipating decisive opposition to Bork, Baker, Meese and Culvahouse told Reagan there was no reason not to choose Bork if that was his wish. ${ }^{245}$

After Bork's defeat, the justice department and White House counsel's office prepared new lists. ${ }^{246}$ Baker and Culvahouse favored Kennedy who they thought would be a compelling witness with broad support. Meese and others in the justice department pushed for their former colleague, Ginsburg, who Baker and Culvahouse thought would be controversial. ${ }^{247}$ Reagan's long-time lawyer, former Attorney General Smith, convinced Reagan to select Ginsburg before

\footnotetext{
${ }^{242}$ Interview with A.B. Culvahouse 48 (April 1, 2004) (transcript available at the Ronald Reagan Oral History Project, Miller Center).

${ }^{243}$ Id. at 48-49, 52; Interview with Howard Baker 5-6 (Aug. 24, 2004) (transcript available at the Ronald Reagan Oral History Project, Washington, D.C.).

${ }^{244}$ Baker interview, supra note 244 , at 6.

${ }^{245}$ Culvahouse interview, supra note 243, at 49; see also GREENBURG, supra note 40, at 49-50 (reporting Reagan administration surprised by opposition to Bork).

246 YALOF, supra note 27, at 161-62.

${ }^{247}$ SAVAGE, supra note 233, at 176-78; YALOF, supra note 27, at 163.
} 
Baker and Culvahouse could meet with Reagan to say "Anthony Kennedy."248 After Ginsburg withdrew conservatives in the justice department agreed to accept Kennedy's nomination. ${ }^{249}$

Reagan's successor, Bush, also used a hybrid process with input from White House counsel Boyden Gray, the justice department and Attorney General Richard Thornburgh, and White House Chief of Staff John Sununu. Although Gray was disposed to recommend Solicitor General (and former Judge) Kenneth Starr for the Brennan seat, Thornburgh deemed Starr unacceptable reflecting opposition from others in the justice department to their colleague's advancement. Ultimately, Souter, with strong backing from Sununu and Senator Warren Rudman, emerged as Bush's choice. ${ }^{250}$

George W. Bush empowered a committee of Vice President Cheney, Chief of Staff Andrew Card, Miers, Gonzales, Deputy Chief of Staff Karl Rove, and vice presidential chief of staff Scooter Libby. ${ }^{251}$ It interviewed prospective candidates at Cheney’s residence and prepared a short list of five candidates who Bush interviewed over three days after reviewing material on 11 prospective choices. $^{252}$ Roberts and Alito were at the top of the list.

\footnotetext{
${ }^{248}$ Interview with A.B. Culvahouse 54-55, in RONALD REAGAN ORAL HISTORY PROJECT; see also GREENBURG, supra note 40, at 58-59 (noting that Baker's newness limited his influence with Reagan relative to Meese and Smith).

${ }^{249}$ Interview with A.B. Culvahouse, in RONALD REAGAN ORAL HistORY PROJECT at 56-57 (stating that Meese told Baker that "We're standing down").

${ }^{250}$ GREENBURG, supra note 40, at 89-97.

${ }^{251}$ Id. at 189-92; Barton Gellman, Angler: The Cheney Vice Presidency 358-60 (2008); Press Briefing by Scott McClellan (October 3, 2005) http://www.presidency.ucsb.edu/ws/index.php?pid=73156\&st=\&st1=.

${ }^{252}$ Press Briefing with Scott McClellan and Dan Bartlett on the President's Supreme Court Justice Nominee (July 19, 2005) http://www.presidency.ucsb.edu/ws/index.php?pid=66243\&st=\&st1=.
} 
Whereas Johnson had essentially ignored the senate, Clinton took the advice of key senators seriously. Republican Senator Orrin Hatch helped dissuade him from appointing Secretary of Interior Bruce Babbitt by suggesting that nomination would provoke a battle whereas Ginsburg or Breyer would be easily confirmed. ${ }^{253}$

The ultimate decision is accordingly affected by the president's idiosyncrasies, by the preferences of his advisers and their interaction with him. Who has the president's ear affects decisions. Brownell and Rogers were largely responsible for three of Eisenhower's five nominees. Robert Kennedy pushed White and blocked Freund. Rehnquist owed his initial nomination to White House aides. Ford's heavy reliance on Levi enhanced Stevens's chances. Rudman and Sununu helped produce the Souter nomination. Clinton kept the process alive until Ginsburg emerged as a strong late candidate. Conversely, FDR, Truman, and Johnson largely relied on their own judgment as did Bush in choosing Miers. The president's decision-making style and the predilections of those he involves determine the choice.

I). The Anatomy of a Nomination: Taft and Choosing a Chief Justice

No president navigated through more byzantine personal considerations than did President Taft when the chief justiceship fell vacant in 1910. That position, more than the presidency, was Taft's highest ambition. Taft knew Chief Justice Fuller's health was failing. When Taft offered Hughes nomination as associate justice in 1910 he intimated that he might

${ }^{253}$ OrRin Hatch, SQuare Peg: Confessions of A Citizen Senator 180 (2002). 
later name Hughes to succeed Fuller although Taft and Hughes both said no commitment was made. $^{254}$

When Fuller died soon thereafter, Hughes was widely mentioned as his likely successor. Taft's friends, Justices Lurton and Day, told Hughes they favored him and Holmes thought Hughes the likely nominee. Justices Harlan and White, the most senior justices, also sought the honor. Hughes was invited to meet with Taft on December 11, 1910 but, as he prepared to leave for the White House 30 minutes later, a second call cancelled the appointment. The following day Taft named White. ${ }^{255}$

Perhaps Taft thought White the more meritorious choice. Hughes's biographer, Merlo Pusey, wrote that a delegation of senators persuaded Taft that the other justices would oppose Hughes's elevation given his youth and recent appointment and that naming Hughes would upset Taft's former friend, but increasingly his rival, Theodore Roosevelt. ${ }^{256}$ The other justices may

\footnotetext{
${ }^{254}$ See Charles Evans Hughes, The Autobiographical Notes of Charles Evans Hughes, 159-60 (David J. Danelski \& Joseph S. Tulchin eds., 1973). Taft wrote Hughes that "[ $t]$ he Chief Justiceship is soon likely to be vacant and I should never regard the practice of not promoting Associate Justices as one to be followed." Taft added that "this suggestion is only that by accepting the present position you do not bar yourself from the other, should it fall vacant in my term." Taft added a P.S. two paragraphs later which both clarified, and obfuscated, his apparent meaning. He cautioned:
}

"Don't misunderstand me as to the Chief Justiceship. I mean that if the office were now open I should offer it to you and it is probable that if it were to become vacant during my term, I should promote you to it; but, of course, conditions change, so that it would not be right for me to say by way of promise what I would do in the future. Nor, on the other hand, would I have you think that your declination now would prevent me offering you the higher place, should conditions remain as they are."

In accepting the Associate Justiceship, Hughes assured Taft that his "expressions regarding the Chief Justiceship are understood and most appreciated." Hughes acknowledged that Taft "properly reserve[d] entire freedom" and Hughes accepted what was offered without wishing Taft "to feel committed in the slightest degree." If Fuller left the Court, Hughes would wish for Taft "to act freely and without embarrassment in accordance with your best judgment at that time."

${ }^{255}$ Id. at $168-69$.

${ }^{256}$ Merlo Pusey, I Charles Evans Hughes 280-81 (1951); see also Paul A. Freund, Charles Evans Hughes as Chief Justice, 81 HARV. L. REV. 4, 4-5 (1967) (citing Court and Senate preferences for White). 
have sent word that they preferred White. Alternatively, Alpheus Mason suggested that Taft may have seen White's nomination as a way to court the Catholic vote for 1912. ${ }^{257}$

Others suggest a different explanation. Appointment of Hughes would likely foreclose Taft's chance of ever becoming chief justice. Mortality tables made the 65 year old White a more appealing choice. Henry Abraham writes: "And the more the president pondered Hughes's 48 years and excellent health, the less convinced he became that he should promote him—after all, it was the post Taft wanted for himself." ${ }^{258}$ In appointing a Catholic and a Democrat, Mason suggests Taft might establish a precedent for a Democratic president to name a Republican Protestant like Taft. Although noble motives may have influenced the decision, Mason concludes in appointing White Taft "overlooked no contingency that might improve his own chances of winning the office which, in his mind, ranked above that of President."259

\section{J). Conclusions on Presidential Idiosyncrasy}

Although Taft's predicament was sufficiently extraordinary to defy repetition, the story illustrates that presidential personality and ambition affects Court choice. That should not surprise. America invests enormous resources in choosing a president due to the widespread belief that it matters who holds that position. One would expect the identity of the president to affect who is nominated to the Court. The various approaches, outlooks, temperament, likes and

\footnotetext{
${ }^{257}$ MASON, William Howard TAFT supra note 40, at 39.

258 ABRAHAM, supra note 4, at 134; see also PUSEY, supra note 256, at 280-81 (suggesting Taft may have weighed this as a "remote factor.").

${ }^{259}$ MASON, WILliam HOWARD TAFT supra note 40, at 39-40 (“The appointment of Hughes would almost certainly have precluded any possibility of ever realizing [Taft's ambition to be Chief Justice]; the elevation of White would not.").
} 
dislikes of different presidents make it impossible to ignore the impact of presidential idiosyncrasy.

\section{A Taxonomy of Supreme Court Nominations}

This sketch of considerations which have shaped Supreme Court nominations since 1900 counsels a skeptical view of efforts to reduce the enterprise to scientific explanations. Surely Professor Nemacheck is correct that presidents act strategically and prefer to nominate those who are ideologically agreeable and likely to be confirmed. ${ }^{260}$ Yet those objectives sometimes yield to others. The reality a president encounters, and the person who encounters it, varies from choice to choice. Selection turns on the interaction between pool, context and idiosyncrasy and each factor consists of various components.

Of course, presidents are likely to choose candidates with a compatible philosophy yet it seems dubious to suggest that, absent confirmation restraints, they will necessarily try to choose the option who is most "ideologically compatible." ${ }^{261}$ Constructing such a measure and locating the president and those on the short list is a problematic enterprise. Franklin Roosevelt had a free hand yet one cannot plausibly conclude that he was more "ideologically compatible" with Black than with Reed, with Reed over Frankfurter, with Frankfurter over Douglas, and so on. All agreed with him on the issues which concerned him. Later when they encountered constitutional questions beyond FDR's agenda, Black and Douglas wound up being closer ideologically than either was to Reed or Frankfurter. Nixon chose Powell and Rehnquist from the same pool but not because they were the two options closest to him ideologically.

\footnotetext{
${ }^{260}$ NEMACHECK, supra note 5, at 133-34.

${ }^{261}$ Id. at 127.
} 
Even if a reliable measure existed to compare a president's judicial philosophy to those of prospective nominees, contextual factors other than ideological similarity and confirmability affect the choice. Facing a difficult reelection campaign, Wilson needed help from progressives. Far from exalting confirmability, he invited a battle by choosing the controversial Brandeis to solidify and broaden his base. Brandeis may have resembled him ideologically, but how can one conclude that ideology, not politics, dictated the choice?

Nor is it plausible to believe that Harding chose Taft, Hoover chose Hughes, FDR chose Stone, and Eisenhower chose Warren because they were ideological twins. Each nominee was a formidable figure. Harding, Hoover and Eisenhower wanted to appease a powerful Republican leader and coopt his supporters, Eisenhower had a promise to keep and FDR wanted to model bipartisanship to unite a country facing war. Surely Roosevelt did not feel ideologically closer to Stone than to Jackson, the confidante to whom he had promised the position. Truman thought bipartisanship important at the beginning of his term and named Republican Burton. Absent the coming war might FDR have elevated Jackson and Truman have chosen someone else, perhaps poor Schwellenbach?

Nixon chose Haynsworth, Carswell, Powell and Rehnquist to reward southern support in 1968 and cultivate it for 1972 even though other choices would have been more confirmable (than all but Powell). Reagan had a public commitment to choose a woman; that constraint, not ideological compatibility or confirmability, helped dictate the O'Connor choice coupled with her support from some who had the president's ear. O'Connor may have been closer to Reagan ideologically than other women on the list but one suspects that Reagan might have found Paul 
Laxalt or William Clark a closer ideological soul mate as well as friend. ${ }^{262}$ Harding had a promise to Sutherland, Truman to Minton, Eisenhower to Warren, Kennedy to Goldberg.

Idiosyncrasy, too, affects selection. Roosevelt, Truman, Kennedy and Johnson tended to choose friends or insiders whereas Hoover, Eisenhower, Nixon and Reagan largely favored outsiders. Even beyond these contrasting inclinations, the simple chemistry, or lack thereof, between two people may make a difference. Reagan hit it off with O'Connor, Rehnquist, and Scalia, George H.W. Bush did with Souter. Breyer's meeting with Clinton went poorly, which created an opening for Ginsburg who had been low on Clinton's list. Her meeting went well, Cuomo withdrew and she was selected.

Harding, Truman, Eisenhower and Kennedy kept their promises to Sutherland, Minton, Warren and Goldberg but Truman did not keep his pledge to Schwellenbach. Did Truman regard promises, or that promise, differently than did the others? Or did further exposure convince him that, whereas Minton was worthy Schwellenbach was not?

Different presidents react to the same conduct in different ways. FDR did not keep Frankfurter off the Court for declining to serve as Solicitor General; Kennedy, at the urgency of his brother, did deny Freund. Did that different treatment reflect differing temperament of the two presidents, their different relationships with the two Harvard law professors, the extraordinary influence of one president's brother or the fact that Frankfurter received FDR's third appointment whereas JFK only made two?

\footnotetext{
${ }^{262}$ Cf. NEMACHECK, supra note 5, at 11-13 (suggesting O'Connor's gender insufficient explanation given presence of other women on short list), 152-53 (providing names of those considered).
} 
The nominations any president makes may not follow a consistent pattern. Theodore Roosevelt had no relationship with Holmes or Day but Moody was his attorney general and close friend. Wilson appointed Brandeis, one of the greatest justices as well as McReynolds, a bigoted reactionary. Wilson knew McReynolds and Brandeis but not his third nominee, Clarke. Eisenhower appointed an eminent politician and four sitting federal judges. George W. Bush nominated two relatively young conservative federal judges with imposing credentials, neither of whom he knew well, and Miers, his long-time friend and lawyer, whose qualifications were modest and whose conservative credentials were suspect. In explaining the Miers choice, Bush celebrated the fact that she was not a judge, but his other two nominees came from the federal bench and Alito had served 11 years in that role. ${ }^{263}$

Such seemingly inconsistent behavior by the same president should not really surprise. The pool changes each time. Even when presidents repeatedly consider many of the same candidates, as did Franklin Roosevelt or Reagan or George W. Bush, for instance, the pool always lacks the person(s) previously chosen.

Moreover, inconsistent behavior may reflect changing context. Wilson faced different constraints in 1914 when he chose McReynolds, than he did two years later when he selected Brandeis. Eisenhower had a promise to fulfill and was naming a chief justice when he named Warren at the beginning of his term. Thereafter, he wanted to dissociate himself from the conduct of his predecessor by selecting judges with whom he lacked any chose relationship.

\footnotetext{
${ }^{263}$ Press Briefing by Scott McClellan (October 31, 2005) http://www.presidency.ucsb.edu/ws/index.php?pid=73323\&st=\&st1 $=$.
} 
Finally, presidents may act inconsistently because they change their mind regarding what factors are important. Or they may value several different criteria and simply strike the balance differently at different times as the pool and context changes.

And at times the reasons for selection may be inscrutable. Why, for instance, did Roosevelt nominate Frankfurter to the third vacancy after telling him he was committed to naming a westerner after having replaced westerner Sutherland with southerner Reed? Was it because Roosevelt's associates persuaded him Frankfurter could do intellectual battle with Hughes? Was it because Roosevelt's first two appointees, Black and Reed, seemed political partisans of mediocre legal ability whereas Frankfurter would add luster to the Court? Did Roosevelt wish to make a gesture to Jewish Americans at a time when he was unresponsive to the Zionist effort to create a Jewish state or to mounting evidence of Nazi genocide? Was it because Cardozo's seat was vacant and Brandeis's health was failing so Frankfurter's appointment would not place two Jewish men from Massachusetts on the Court for long? Was it because Roosevelt and Frankfurter were friends and the President appreciated his loyalty? ${ }^{264}$

Obama's two choices demonstrate the variability of presidential behavior. He nominated Judge Sonia Sotomayor and Solicitor General Elena Kagan to fill the first two Supreme Court vacancies which occurred during his term. Both are women, both are lawyers, both have imposing credentials including Ivy League pedigree. There the easily discernible relevant similarities end.

Sotomayor was a judge on the United States Court of Appeals for the Second Circuit and had been on the federal bench for 17 years, more than any first time appointee to the Supreme

\footnotetext{
${ }^{264}$ See PARRISH, supra note 148 , at 276-78.
} 
Court. By contrast, Kagan had no judicial experience, a hole in her resume which distinguished her also from the 12 immediately preceding persons confirmed for the Court. Obama had known Kagan for nearly two decades and had appointed her to a high governmental position; he met Sotomayor shortly before choosing her. Sotomayor was a "first," the first Hispanic named to the Court; Kagan was not a "first" and her ethnic group, Jewish-Americans, already was overrepresented according to some observers. ${ }^{265}$

Obama chose Sotomayor and Kagan in unique political contexts which differed from those in which his predecessors acted and from each other. Sotomayor was the first nominee of a new president, barely four months in office. He had high approval ratings and faced a senate consisting of 59 (soon to be 60 with the seating of Senator Al Franken) Democrats but one whose Republican members had proven willing to filibuster nominees. He had an ambitious legislative agenda and faced a daunting array of international and domestic crises. These other demands made Obama averse to committing extensive political capital to a nomination battle. As the first African-American president, Obama was a metaphor for the American Dream and for opening doors to groups previously excluded from leadership positions. His predecessor had recently nominated a man to fill the vacancy created by the retirement of O'Connor, one of the two women justices, and the last three presidents had considered, but passed over, Hispanic candidates for the Court to the growing dissatisfaction of that growing electoral constituency. Sotomayor's personal narrative in some ways resembled Obama's and the themes he emphasized in his campaign and administration. Obama used the announcement of her nomination and the ceremony celebrating her confirmation to echo those notes. Nominating Sotomayor allowed

\footnotetext{
${ }^{265}$ See, e.g., Patrick J. Buchanan, Are Liberals Anti-WASP?, WorLdNETDAILY COMMENTARY (May 13, 2010), http://www.wnd.com/index.php?fa=PAGE.view\&pageId=153417.
} 
Obama to sound an appealing theme, please an important demographic group, and choose a confirmable nominee whose selection would not interfere with other matters on the agenda.

The context had changed when Obama made his second nomination the following year. The Sotomayor nomination had, of course, removed the pressure to name a Hispanic to the Court. Obama's approval rating had declined, his party had experienced some setbacks, and the midterm election campaigns were well underway with the indicators trending against the Democrats. Kagan, having served as Solicitor General for a year and a half and having argued six times before the Court, was a more plausible candidate than the year before. Obama's two leading alternatives, Judges Diana Woods and Merrick Garland, seemed more likely to antagonize the right or left respectively than did Kagan. Having nominated Sotomayor with his first choice, he may have seen Kagan as the safest pick available to him. A relatively smooth confirmation in an election year no doubt had some appeal. Finally, Kagan had a reputation for working across the aisle. Obama may have thought she could appeal to one or more of the five conservative members of the Court.

Obama was apparently not troubled by leaving the Court without a Protestant member or without one who attended a law school other than Harvard, Yale or Columbia. Perhaps a different president would have weighed those factors more heavily than did he. Perhaps they will constrain the next Supreme Court nomination, whether made by Obama or his successor.

\section{The Dynamic Nature of Supreme Court Selection}

The discussion thus far has largely assumed that the period since 1900 provides data to accurately portray Supreme Court selection as it now exists. This premise needs now to be qualified. That period is valid to illustrate the three-variable taxonomy which did and does 
provide an analytical tool to assess presidential selection of Supreme Court nominees.

Moreover, many of the particular components of each variable apply. Even where some specific considerations are now obsolete or nearly so, they often represent more general concepts. For instance, presidents no longer emphasize geography or religion in choosing nominees yet those anachronistic categories remind us that representation and diversity have long been a consideration and are surrogates for their contemporary successor categories such as race, gender and ethnicity. Similarly, future presidents obviously cannot appoint "firsts" from those groups which have already provided justices but this motivation will presumably manifest itself with respect to groups whose members have not yet served.

Yet presidential selection of Supreme Court nominees has not been a stable enterprise since 1900. Although each president has exercised the same constitutional power, the nomination process has changed in fundamental ways which have affected presidential calculations. In addition to short-term contextual conditions, modern presidents act in a different political universe than did their predecessors of a century or half-century ago. Some of the discussion so far has hinted at some of these changes. It is useful now to focus on them.

First, the growth of the executive branch generally, and the White House staff specifically, have provided presidents with greater resources to scrutinize Supreme Court nominees. In the $19^{\text {th }}$ and early $20^{\text {th }}$ century, senators, cabinet members and certain justices often significantly influenced nominations. Relatively few participated in the selection process. ${ }^{266}$ Such figures sometimes still make a difference but their leverage has diminished as other players have emerged. The justice department and White House have expanded since the New Deal,

${ }^{266}$ See, e.g., NEMACHECK, supra note 5, at 84-85 (describing Franklin Roosevelt's decision-making process). 
providing much greater capacity in the executive branch to evaluate and vet prospective nominees. Although the development originally pulled the selection process towards the justice department, the more recent growth of the White House staff in general, and of the White House counsel in particular, have expanded presidential resources and drawn the process into the White House. A tiny number of professionals worked in Franklin Roosevelt's White House but by the Nixon administration, the president could call upon White House attorneys as well as political advisers in considering prospective nominees. ${ }^{267}$ The justice department or particular attorneys general may still be involved, particularly those close to the president, but increasingly the White House has played a large role. ${ }^{268}$ Recently, the Vice President's office has played an important role. Al Gore was part of the group which met with Clinton regarding his nominations. ${ }^{269}$ Dick Cheney played a major role in screening Supreme Court nominees for George W. Bush. Prospective candidates were interviewed at the Vice President's residence in a process Cheney directed. ${ }^{270}$ Vice President Joe Biden conducted separate interviews of those on Obama's shortlist. $^{271}$

Second, since the $17^{\text {th }}$ Amendment to the Constitution was ratified in 1913, senators have been elected by popular vote rather than by the state legislature. ${ }^{272}$ Accordingly, they are more responsive to public opinion in their states and less susceptible to persuasion by home state

\footnotetext{
${ }^{267}$ MALTESE, supra note 47, at 117-20 (tracing development of White House staff); DAVID M. O'BRIEN, STORM CENTER: The SUPREME COURT IN AMERICAN POLITICS 40-41 (7th ed. 2005); YAlOF, supra note 27, at 12-13.

${ }^{268}$ See generally NEMACHECK, supra note 5, at 36, 43, 91-106; YALOF, supra note 27, at 13-14.

${ }^{269}$ YALOF, supra note 27, at 197, 200-01.

${ }^{270}$ GeLLMAN, supra note 252, at 358-60; see also GREENBURG, supra note 40, at 190-93. 252

${ }^{271}$ See, e.g., Ben Feller, Obama, Biden InterviewDiane Wood for Supreme Court, CHR. SCI. Mon. , May 6, 2010; Peter Baker and Jeff Zeleny, Obama Hails Judge as 'Inspiring, ' N.Y. TimEs, MAY 26, 2009.

${ }^{272}$ U.S. CONST. amend. XVII; see, e.g., GERHARDT, supra note 21, 212-14.
} 
legislators. Direct election of senators did not immediately emerge as an important influence on Supreme Court selection. Instead, it assumed significance only later as other developments made the process more publicly accessible.

Third, changes in senate procedure made the process much more transparent. Prior to 1929, most confirmations were conducted in secrecy. Special action was required to open the proceedings. Such arrangements were made in 1916 for the Brandeis nomination but not on most other occasions. Since 1929, hearings and floor debate have occurred in open settings. ${ }^{273}$ Even so, the senate often did not hold hearings or conducted perfunctory sessions. There were no hearings to consider the nominations of Byrnes, Wiley Rutledge and Harold Burton in the 1940s and 1950s; the senate spent only one day and between 23 and 58 pages of hearings on the nominations of Sherman Minton, Charles Whittaker, Byron "Whizzer" White and Fortas (1965). Even the nominations of Warren Burger in 1969 and Harry Blackmun in 1970 required a single day and only 116 and 134 pages respectively. ${ }^{274}$ The level of scrutiny changed dramatically with the Bork confirmation which spanned 12 days of hearings and produced a transcript of 6,511 pages. $^{275}$

Fourth, testimony by nominees is a relatively recent practice. Although Harlan Fiske Stone became the first nominee to testify in 1925 (at his request to rebut charges against his administration of the justice department) his appearance did not create a new expectation. The

\footnotetext{
${ }^{273}$ MALTESE, supra note 47, at 37, 52, 86-87; YALOF, supra note 27, at 14-15; Freund, Appointment, supra note 78, at 1157; Whittington, supra note 57, at 434 (relating greater transparency in senate's conduct of business to change to popular election of senators).

${ }^{274}$ MALTESE, supra note 47 at 90-91; YALOF, supra note 27, at 14-15.

${ }^{275}$ MALTESE, supra note 47, at 90-91. Even relatively easy nominations like those of Kennedy and Souter lasted several days and produced a record in excess of 1000 pages. $I d$. at 90-91.
} 
next six nominees did not appear; Felix Frankfurter testified, reluctantly, and at the request of the senate subcommittee. Only two of the next 11 nominees testified. Beginning with John Marshall Harlan's nomination in 1955, every nominee has appeared (unless the nomination was withdrawn before hearings were held). ${ }^{276}$

Fifth, technological change has dramatically altered the context in which nominees are chosen. Hearings have been televised since 1981 and the presence of the cameras has changed behavior and introduced new considerations. ${ }^{277}$ Presidents now have reason to weigh how a nominee will come across in that medium. The television screen was not kind to Judge Robert Bork, a factor which may have contributed to his defeat. ${ }^{278}$ By contrast, it may have helped John Roberts, a photogenic nominee. Television and other electronic forms of disseminating information make data, and rumors, about prospective and legal nominees more accessible. The advent of cable news and the internet creates a continuous demand for news and a never ending news cycle. ${ }^{279}$

Sixth, non-governmental groups have assumed an increased role in the process. The American Bar Association has evaluated most nominees since 1954. Whereas interest groups rarely participated in the confirmation process during the first half of the period, their involvement is now commonplace. A variety of interest groups with competing agenda have

\footnotetext{
${ }^{276}$ MALTESE, supra note 47, at 92-112.

${ }^{277}$ See CARTER, supra note 3, at 16-18; DAVIS, supra note 21, at 15 (describing confirmation process now as "media-oriented exercise"); GERHARDT, supra note 21, at 234-49; see also Lee Epstein, Jeffery A. Segal, Nancy Staudt \& Rene Lindstadt, Role of Qualifications in the Confirmation of Nominees to the U.S. Supreme Court, 32 FLA. ST. U. L. REV. 1145, 1151-52 (2005) (describing increase in print media attention to confirmations).

${ }^{278}$ GREENBURG, supra note 40, at 51.

${ }^{279}$ DAVID R. STRAS, Understanding The New Politics Of Judicial Appointments, 86 TEX. L. REV. 1033, 1064-65 (2008) (describing increased role of media); YALOF, supra note 27, at 17.
} 
sought to influence decisions regarding nomination and confirmation. This involvement, once episodic, now is routine at all stages of the process. ${ }^{280}$ By nature, they are committed to particular agendas and the objectives which animate their existence dwarf all other considerations. They expect their allies in the senate to help them achieve their goals. ${ }^{281}$

Seventh, the greater appreciation that the Court plays a significant role on controversial issues has increased the perceived stakes of nominations. Members of the public and interest groups have intense feelings on hot button issues like abortion, same sex marriage, and affirmative action which the Court decides or is likely to consider. The realization that the Court will likely play a consequential role on such issues has drawn greater attention to presidential choices ${ }^{282}$ and has raised the stakes for presidents and senators in selecting nominees and deciding how to vote respectively.

Eighth, the Senate has become a more challenging body for presidential nominations due to two additional changes. Cross-party control has become a more frequent reality. No president submitted a nominee to a cross-party Senate from 1900 to 1954 (and cross-party control only occurred during that time from 1947 to 1949). Since 1955, the Senate has been subject to cross-

\footnotetext{
${ }^{280}$ See DAVIS, supra note 21, at 10, 28, 82-86 (2005); GERHARDT, supra note 21, at 217-33; O'BRIEN, supra note 267, at 44-45, 74, 78; YALOF, supra note 27, at 15-17; Lee Epstein, Jeffery A. Segal, Nancy Staudt \& Rene Lindstadt, Role of Qualifications in the Confirmation of Nominees to the U.S. Supreme Court, 32 FLA. ST. U. L. REV. 1145, 1150-51 (2005) (describing explosion of interest group involvement from 1953-1994); STRAS, supra note 279, at $1062-64$ (same).

${ }^{281}$ Stras \& Scott, supra note 1, at 1890-91.

${ }^{282}$ See, e.g., COMISKEY, supra note 161, at 7(attributing greater senate role to Brown v. Board of Education and subsequent cases); EISGRUBER, NEXT JUSTICE, supra note 3, at 142 (associating Warren Court decisions with subsequent move to ideological nominees); Orrin G. Hatch, The Politics of Picking Judges, 6 J.L. \& PoL. 35, 35-36, 53 (1989) (tracing politicization of process to judicial activism); Robert B. McKay, Selection of United States Supreme Court Justices, 9 U. KAN L. REV. 109, 111 (1960) (tracing elevated interest to Brown v. Board of Education).
} 
party control for $29 \frac{1}{2}$ of the 56 years. Five of the 11 presidents since then submitted 16 of the 33 nominees to a Senate the opposing party controlled. ${ }^{283}$

The challenge has been compounded more recently by the disappearance of the Senate's center. The demise of moderate Republicans and conservative Democrats has made it more difficult for presidents to win cross-party votes for their nominees.

This latter development relates to the increased polarization of American politics. Activists who vote in primaries tend to reflect the extremes of their parties, a development which has contributed to the changes in the Senate and has reduced the availability of cross-party nominees. Recent presidents have not considered such figures because few appealing such candidates now exist.

Taken together, these developments have presented recent presidents with a different reality when making nominations. The increasing frequency of divided control of the White House and senate means that many presidents submit their nominees to a less receptive body, a circumstance which itself presents a greater challenge.

Even under conditions of unified government, the president faces more intense constraints. Nominations are now highly visible to the public. Nominees must now appear before the Senate judiciary committee in televised proceedings. Modern media assures that information and discussion regarding a Court nominee will be widely and continuously disseminated. The president's base and cross-party partisans are likely to care deeply about the choice and assess the nominee based upon the perceived impact on high profile litmus test issues. Interest groups will be intensely engaged because their constituents expect them to be.

${ }^{283}$ See text at n. 54 . 
These factors motivate senators on each side to become engaged and to perceive themselves as more accountable to their supporters. They recognize that their actions on Court nominations are among their most visible public actions. ${ }^{284}$ The increased transparency limits their flexibility, particularly if they plan to seek re-election and if their term expires soon. These changes have transformed the stakes for senators in the process.

To be sure, the institutionalization of the executive branch and the White House gives the president more tools to assess the merits of competing candidates and the implications of different choices. Yet the advantage from this enhanced capacity, helpful though it is, does not overcome the constraints these developments impose.

In response to these changes, the senate has provided a greater obstacle to presidential nominations than was true earlier in the century. ${ }^{285}$ Dividing the period from 1900 roughly into two halves (1900-1955, 1956-2011), illustrates that confirmation has recently been less certain than was true during the first part of the period. Only one nomination was defeated during the first half ${ }^{286}$ yet seven were unsuccessful during the more recent period. ${ }^{287}$ Even successful nominees attract more opposition. During the first half, 32 of the 35 successful nominees (92\%) received at least $75 \%$ of the votes cast in the senate. During the second period, only $75 \%$ of successful nominees achieved that threshold. Of the last four nominees, one was withdrawn and the other three averaged 37 negative votes.

\footnotetext{
${ }^{284}$ STRAS, supra note 279 , at 1066-67.

${ }^{285}$ See, e.g., COMISKEY, supra note 161, at 11-13, 152.

${ }^{286}$ Judge John Parker was defeated in 1930 by a 41-39 vote in a Republican controlled Senate.

287 The nominations of Fortas and Thornberry were filibustered in 1968; Haynsworth, Carswell and Bork were rejected; Douglas Ginsburg and Miers were forced to withdraw. George W. Bush's withdrawal of Roberts in 2005 to renominate him as chief justice is not, of course, included here since he obviously would have won confirmation.
} 
In addition to confirmation becoming more precarious, the stakes for the president have increased in another respect. Presidents know their nominees will be highly scrutinized by the media, opposing interest groups and the senate. The increased visibility and interest means the president is more likely to be measured by his choice of a Court nominee than was true a halfcentury ago. They will be affected not simply by whether a nominee is confirmed and how she acts on the Court but by how a nominee is perceived during the process. Presidents want to name justices whose appointments will reflect well on them, either to enhance their current political standing or to contribute to their legacy, or both. Supreme Court nominations, more than virtually any but the choice of a running mate send messages to officials, groups and citizens about the president and his values. The increased visibility now presents more risk but also greater opportunity for the president. He can exploit a nomination to enhance his own standing with important constituencies or the public at large. ${ }^{288}$

Although presidents still operate within the same formal arrangements as did their predecessors a century or half-century ago, the president now encounters a very different system. The transformation has occurred through a series of informal changes in the operation of the selection process. Most of the changes occurred independent of one another. Many--the increased salience of issues on the Court's docket, the polarization of politics, the change in media--occurred entirely independent of the confirmation process.

In this respect, the change in the selection process of Supreme Court nominees mirrors that in the selection of vice-presidential running mates during the latter half of the twentieth century. There a range of informal changes in other institutions and in the larger society-the

\footnotetext{
${ }^{288}$ DAVIS, supra note 21, at 130 (discussing new opportunities for presidential "image making" through the process).
} 
growth of the presidency, decline of party leaders, nationalization of politics, technological change in media and air travel, and move to a presidential primary system — changed the dynamics of running mate selection. Instead of party leaders engaging in ticket-balancing at the convention with little input from the presidential nominee, the system came to be dominated by the presidential candidate, removed from the convention and generally focused on the extent to which a prospective nominee was nationally acceptable. ${ }^{289}$ Supreme Court selection, like the choice of a running mate, has evolved in response to the changing political landscape in which the decision is made.

As such, presidential selection of nominees for the Court presents yet another example of the way in which constitutional institutions evolve even without formal change. Presidents act differently in choosing Supreme Court nominees in response to the changed political landscape in which the choice is made.

\section{The Impact of the Changes}

Although Supreme Court nominees remain the product of the interaction of pool, context and idiosyncrasy the president faces new constraints. The increased transparency, visibility, and acrimony of the process influence presidential decisions in multiple ways. In the relentlessly unforgiving world of 24 hour cable news and internet, presidents have increased reason to choose nominees who present themselves as plausible justices. Nominees with unimposing credentials or modest aptitudes not only will provide wavering senators a reason to vote "no." They will also reflect badly on those who chose them. A nominee has to be able to vindicate

\footnotetext{
${ }^{289}$ See GolDSTEIN, supra note 20, at 15-89, 301-03; Joel K. Goldstein, Resolved, the vice presidency should be abolished: con, in Debating the Presidency: Conflicting Perspectives on the American Executive 183 (Richard J. Ellis \& Michael Nelson eds. 2d ed. 2010).
} 
himself or herself in televised hearings before the senate judiciary committee, a body which will include some members who will be intent on embarrassing the witness and the president who chose her. The nominee may be in the hot seat but the president who made the nomination is also a target. The nominee's vulnerabilities will be exploited to tarnish the president.

This changed context makes it more difficult to nominate those who are not well-versed in high profile public law topics. Bush's selection of Miers reveals the hazard of choosing someone with modest credentials. Roughly three weeks after nominating Miers, Bush withdrew her name after receiving advice from White House aides that her lack of knowledge would prevent her from performing adequately at her hearings. ${ }^{290}$ Her weakness as a candidate would provide opportunity for Bush's critics to attack him, further compounding Bush's growing political weakness. ${ }^{291}$

Although these developments may provide incentive to avoid nominees whose qualifications are lackluster, they also have less salutary consequences. They may also make it difficult for presidents to choose those who have engendered controversy because they have boldly explored new vistas in the law. Those with lengthy paper trails in the service of controversial causes may seem unappealing nominees in our polarized political climate made more so by an information age media which is structured to exacerbate differences. Presidents may be inclined to avoid such candidates in favor of those whose views on litmus test issues are more mysterious. A contemporary version of Brandeis, if such a figure can be imagined, may present too great a risk for a modern president. A more cautious, less controversial candidate

\footnotetext{
${ }^{290}$ GREENBURG, supra note 40, at 279-84; Statement Announcing the Withdrawal of the Nomination of Harriet E. Miers To Be an Associate Justice of the United States Supreme Court, 2 PUB. PAPERs 1612 (October 27, 2005).

${ }^{291}$ GREENBURG, supra note 40, at 278-84.
} 
may seem the more prudent choice particularly for a president who faces other challenges and does not want a contentious Court battle to divert resources from other priorities.

It is no coincidence that most recent nominees have been lower court judges. Although the propensity of presidents to name judges has been exaggerated by focusing on those appointed rather than first choices, ${ }^{292}$ presidents do often gravitate to judges for several reasons. A judicial record may provide clues to judicial philosophy while insulating the jurist from the occasion to expound on hot button topics. Prior confirmation suggests the judge has cleared a vetting hurdle and may create a presumption in favor of approval. The title "Judge" provides an apparent qualification even though the role of a Justice is different in critical respects. And judicial experience may familiarize a judge with a wide range of doctrine so she can present herself as knowledgeable during testimony.

Notwithstanding Kagan's selection, the modern process may raise the risks of choosing some administration insiders. So doing raises the possibility that unfriendly senators will use the hearings to attack and discredit administration conduct, a concern which made Babbitt a costly nominee for Clinton. Moreover, some senators may seek to uncover communications between the President and the nominee, a strategy which complicated Miers' nomination.

The modern process still involves an interaction between pool, context and presidential idiosyncrasy but the developments outlined above tilt a president's calculations differently than in earlier times. Ideology is understood to be more important, confirmation more difficult, the process far more transparent and contentious, all of which elevates the risks to the president.

\footnotetext{
${ }^{292}$ For instance, Clinton wanted to appoint Cuomo and Mitchell but they (as well as Riley) declined. Bush nominated Miers and Obama, Kagan. Thus, although federal judges have filled five of the last six vacancies presidents nominated, or wanted to nominate, elected or appointed officials to four of those six positions.
} 
These changes decrease the likelihood presidents will choose cronies or lackluster candidates. They also diminish the chance they will nominate a Brandeis, a Cardozo, a Warren or a Hughes. They seem to promote the likelihood that presidents will more often seek federal judges than those whose primary career work has been in elected or high-level appointed positions.

\section{Conclusion}

Of course, presidents want to appoint ideologically compatible nominees, they want their choices to be confirmed and occasionally they must strike accommodations between these two goals. Yet these are not their only objectives in choosing nominees. Presidents also want to protect and improve their own public stature, to avoid jeopardizing other aspects of their program, and to respond to demands of important demographic groups. These considerations may compete and may weigh differently for different presidents and at different times.

Ultimately, future, like past, choices will turn on the interaction of pool, context and selector. In all likelihood, presidents will nominate able lawyers whose philosophies they find congenial, who they deem confirmable and whose selections they think will reflect well on them. Beyond that, each president will weigh differently a range of considerations based upon the options he has, the constraints he perceives, and the distinctive mix of attributes he brings to the decision. Those collective calculations of a number of presidents will largely determine the composition of the Court which interprets the Constitution.

The new regime seems likely to encourage the appointment of able justices. It is less clear that it will produce those with political skill. Ironically, in an age in which the Court's work is increasingly seen as political, relevant and controversial, those appointed increasingly seem unschooled (and often uninterested) in important political arts such as compromise and 
anticipating the societal impact of alternative choices. That development has resulted from the way the system of selecting nominees has responded to societal changes. It is a byproduct worth watching, and remedying. 